Article

\title{
Early Jurassic-Early Cretaceous Calcareous Nannofossil Biostratigraphy and Geochemistry, Northeastern Iraqi Kurdistan: Implications for Paleoclimate and Paleoecological Conditions
}

\author{
Nagham Omar ${ }^{1, *(\mathbb{D}}$, Tom McCann ${ }^{1}$, Ali I. Al-Juboury ${ }^{2}$, Maria A. Ustinova ${ }^{3}$ and Arkan O. Sharezwri ${ }^{4}$ \\ 1 Institut für Geowissenschaften-Geologie, University of Bonn, Nussallee 8, 53115 Bonn, Germany; \\ tmccann@uni-bonn.de \\ 2 Geology Department, College of Sciences, University of Mosul, Mosul 41002, Iraq; alialjubory@yahoo.com \\ 3 Geological Institute, Russian Academy of Sciences, 119017 Moscow, Russia; ustinova_masha@mail.ru \\ 4 Department of Petroleum Geosciences, Soran University, Soran 44008, Erbil, Kurdistan Region, Iraq; \\ arkan.osman@hotmail.com \\ * Correspondence: s6naomar@uni-bonn.de; Tel.: +49-228-73-4812; Fax: +49-228-73-9037
}

check for updates

Citation: Omar, N.; McCann, T.; Al-Juboury, A.I.; Ustinova, M.A.; Sharezwri, A.O. Early Jurassic-Early Cretaceous Calcareous Nannofossil Biostratigraphy and Geochemistry, Northeastern Iraqi Kurdistan: Implications for Paleoclimate and Paleoecological Conditions. Geosciences 2022, 12, 94

https: / / doi.org/10.3390/ geosciences12020094

Academic Editors: Pierre Pellenard, Emanuela Mattioli, Guillaume Dera and Jesus Martinez-Frias

Received: 20 December 2021 Accepted: 13 February 2022 Published: 17 February 2022

Publisher's Note: MDPI stays neutral with regard to jurisdictional claims in published maps and institutional affiliations.

Copyright: (C) 2022 by the authors. Licensee MDPI, Basel, Switzerland. This article is an open access article distributed under the terms and conditions of the Creative Commons Attribution (CC BY) license (https:// creativecommons.org/licenses/by/ $4.0 /)$.

\begin{abstract}
Early Jurassic- to Early Cretaceous-age calcareous nannofossils from the Sarki, Sehkanyian, Sargelu, Naokelekan, Barsarin and Chia Gara formations are investigated for the first time from the Warte area, northeastern Iraqi Kurdistan. A range of isotopic and inorganic geochemical analyses are carried out in order to reconstruct the paleoecological and paleoclimatic conditions during which the Sarki, Sehkanyian, Sargelu, Naokelekan, Barsarin and Chia Gara formations were deposited. The age of the Sargelu Formation was determined as Bajocian-Callovian based on the first occurrence of Cyclagelosphaera margerelii, Watznaueria britannica, W. fossacincta, W. manivitiae, Watznaueria barnesiae and Watznaueria ovata. Geochemical proxies ( $\mathrm{Sr}, \mathrm{Ca}, \mathrm{Al}, \mathrm{Rb} / \mathrm{Sr}, \mathrm{Sr} / \mathrm{Cu}$ and $\mathrm{Sr} / \mathrm{Ba}$ ) for paleoclimate and paleoecological conditions, along with oxygen isotopes $\left(\delta^{18} \mathrm{O}\right)$ data, suggest that warm and arid climatic conditions were predominant during the Early Jurassic-Early Cretaceous period.
\end{abstract}

Keywords: calcareous nannofossils; stable isotopes; paleoclimate; paleoecology; Jurassic; Iraq

\section{Introduction}

Calcareous nannofossils are the most important carbonate-forming organisms since Jurassic times, and their biostratigraphy and carbon-isotope data commonly provide excellent stratigraphic control [1]. In addition, the relationship between calcareous nannofossils and inorganic geochemical data can be used as a tool to interpret paleoenvironmental and paleoclimatic conditions [2-4]. Similarly, the oxygen isotope geochemistry is used as an indicator of the dominant climatic conditions [5-8]. The Jurassic successions in Iraq are of geological and economic importance and, thus, they have been described in numerous academic theses and research papers, the majority of which have focused on the lithology and depositional environments of the successions and their economic significance [9-13]. A few articles on calcareous nannofossils from the Naokelekan and Chia Gara formations in Iraqi Kurdistan have been published [14,15]. However, detailed studies covering the calcareous nannofossil biostratigraphy of all Jurassic-age formations in northeastern Iraqi Kurdistan have not, to date, been attempted.

The current study focuses on calcareous nannofossil biostratigraphy and related isotopic and inorganic geochemistry of the Early Jurassic- to Early Cretaceous-age formations from the Warte section, northeastern Iraqi Kurdistan, including the paleoecology and paleoclimate proxies. This section, i.e., the Warte section, crops up in a region where calcareous nannofossils from the entire Jurassic system were recorded and analyzed for the first time. The location of this section, and its lack of accessibility (partly due to the political situation) 
means that this work will remain unique for the foreseeable future. The sedimentary succession from the Warte section comprises interbedded shales and carbonates (dolomites and limestones) and rare chert beds. A total of sixty-five samples were selected, covering the entire Jurassic succession, and including the Sarki, Sehkanyian, Sargelu, Naokelekan, Barsarin and Chia Gara formations. While the presence of a Lower Jurassic-Middle Jurassic boundary and a Middle Jurassic-Upper Jurassic boundary interval was confirmed, the position of these boundaries remains unclear. The aim of the present study, therefore, is to determine the stratigraphic position of the lower and upper boundaries of the Middle Jurassic in the Warte succession from northeastern Iraqi Kurdistan based on the detailed analysis of the calcareous nannofossils. In addition, the study aims to reconstruct the paleoecological and paleoclimatic conditions of the Jurassic-Lower Cretaceous succession of the region by integrating calcareous nannofossil data with geochemical analyses.

\section{Geological Setting}

The area of study is situated in the Erbil Governorate, within the region of Iraqi Kurdistan, Northern Iraq $[13,16]$. Northern Iraq lies within the Zagros Basin/Zagros Fold Belt on the northeastern boundary of the Arabian Plate (see Figure 1a for the location and tectonic provinces) [13-18]. The Zagros Basin/Zagros Fold Belt, which covers an area of about $500 \times 103 \mathrm{~km}^{2}$, has a NW-SE length of c. $2300 \mathrm{~km}$, extending from Turkey to SE Iran, and a NE-SW width of 100-300 km [16]. It formed as a result of the collision between the continental Arabian Plate and the continental segments of the Eurasian margin [19-21]. In Iraq, the Zagros Basin/Zagros Fold Belt contains sedimentary rocks ranging in age from Jurassic to Tertiary, i.e., dominated by a thick Mesozoic succession.

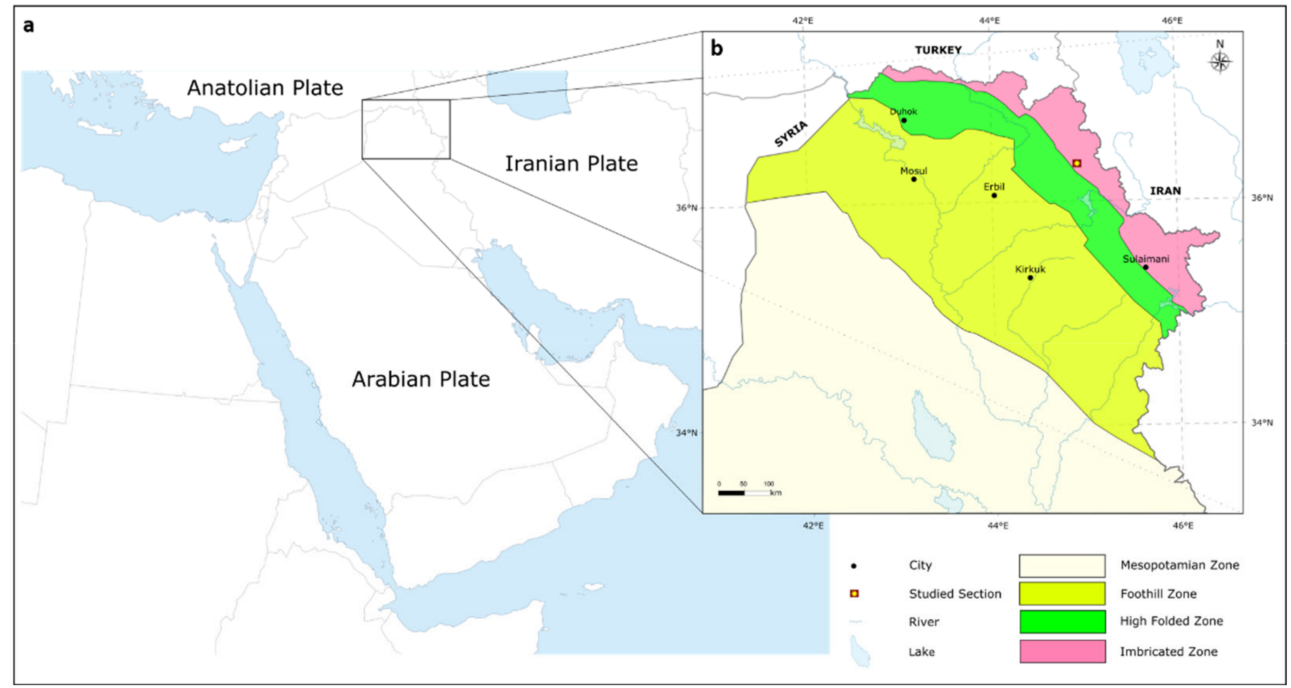

Figure 1. (a) Location of the study area in northeastern Iraqi Kurdistan within the Arabian plate. (b) Geological map of Northern Iraq showing the study area and the structural zones of the Zagros Basin/Zagros Fold Belt.

The present study focusses on the Early to Late Jurassic succession of the Warte area, northeastern Iraqi Kurdistan region. The regional stratigraphy can be subdivided into six formations, namely, the Sarki, Sehkanyian, Sargelu, Naokelekan, Barsarin and Chia Gara formations [22]. The exposed Jurassic formations in Northern Iraq are located as isolated patches within eroded cores and limbs of anticlines in the structural zones of the Zagros Basin/Zagros Fold Belt of Northern Iraq [23]. These structural zones include, from SW to NE, the Low Folded Zone (or Foothills), the High Folded Zone and the Imbricated Zone [24]. The Warte section, which was examined as part of this study, is located within the Imbricated Zone (Figure 1b). The Imbricated Zone of Iraq generally is characterized by marked folding and faulting in the Paleozoic to Cenozoic sedimentary strata [25]. The 
impact of tectonic deformation in this zone is clearly visible in the complex fold geometries that are noted [26].

The Early-Jurassic-age Sarki Formation was first described by Dunnington [27] from the Chia Gara Range of N Iraq as a $300 \mathrm{~m}$ thick carbonate unit [22,24].

The formation consists of limestones, dolomitic limestones, dolomites and shales. An Early Liassic age has been inferred based on the stratigraphic position of the formation between the underlying Upper Triassic Kurra Chine Formation and the overlying Middle Jurassic Sargelu Formation. The lower and upper contacts of the formation are conformable and gradational. The Sarki Formation was deposited in a restricted lagoonal environment [24].

The Early-Jurassic-age Sehkaniyan Formation was first described by Wetzel and Morton in 1950 from the Surdash Anticline, NE of Iraq, as a $180 \mathrm{~m}$ thick carbonate unit [28]. The formation consists mainly of dolomites and dolomitic limestones. A Liassic age was proposed for the formation based on the faunal content, including bivalve (e.g., Lithiotis) and algae (e.g., Boueina hochstetteri). The lower and upper contacts of the formation with the Sarki and Sargelu formations are conformable and gradational [22,29]. The formation was deposited in a restricted lagoonal environment [24].

The Middle-Jurassic-age Sargelu Formation was first described by Wetzel from the Surdash Anticline in the High Folded Zone, NE of Iraq [30]. The thickness of the Sargelu Formation in its type section is about $115 \mathrm{~m}$, and consists of bituminous limestones, dolomitic limestones and black shales with streaks of thin black chert. A Bajocian-Bathonian age was suggested for the Sargelu Formation based on the presence of bivalves (e.g., Bositra buchii). The lower contact with the Sehkaniyan Formation in the type area is usually conformable and gradational, and the contact with the overlying Naokelekan Formation is similar. The formation was deposited in a basinal euxinic marine environment [22,24].

The Late-Jurassic-age Naokelekan Formation was first described by Wetzel and Morton from the Balambo-Tanjero Zone near Rowanduz, NE Iraq [28]. The Naokelekan Formation consists of argillaceous bituminous limestones, dolomites, and shales with beds of black shales in its lower part. An Early Callovian-Kimmeridgian age was proposed for the formation based on the recorded fauna, including belemnites, stromatoporoids, foraminifera and algae [31]. The lower and upper contacts of the formation with the Sargelu and Barsarin formations, respectively, appear to be conformable. The formation was deposited in an euxinic environment in a subsiding or starved basin [22,24].

The Late-Jurassic- age Barsarin Formation was first described by Wetzel in 1950 from its type area in the Balambo-Tanjero Zone near Rowanduz, NE Iraq [32]. The Barsarin Formation consists of limestones and dolomitic limestones. A Kimmeridgian-Early Tithonian age was suggested for the formation based on its stratigraphic position below the Late Tithonian Chia Gara Formation and above the Naokelekan Formation. The lower and upper contacts of the formation appear conformable with both the Naokelekan and Chia Gara formations in the type area. The Barsarin Formation was deposited in a lagoonal or evaporitic environment $[22,24]$.

The Late Jurassic-Early Cretaceous-age Chia Gara Formation was first defined by Wetzel in 1950 from the Chia Gara Anticline in the High Folded Zone of Northern Iraq [30]. The Chia Gara Formation consists of thinly bedded limestones and calcareous shales. A Middle Tithonian-Berriasian age was suggested for the formation. The lower contact with the Barsarin Formation is conformable. The contact with the overlying Garagu Formation is gradational and conformable. The Chia Gara Formation was deposited in a mid-deep shelf environment [22,24].

\section{Materials and Methods}

Sixty-five (65) samples from the Warte section were selected for detailed calcareous nannofossil biostratigraphy, trace element and oxygen stable isotopic geochemistry analyses. The samples cover the entire succession at this location, extending from the Sarki Formation to the Chia Gara Formation (see Figure 2 and Table 1 for sample locations). 


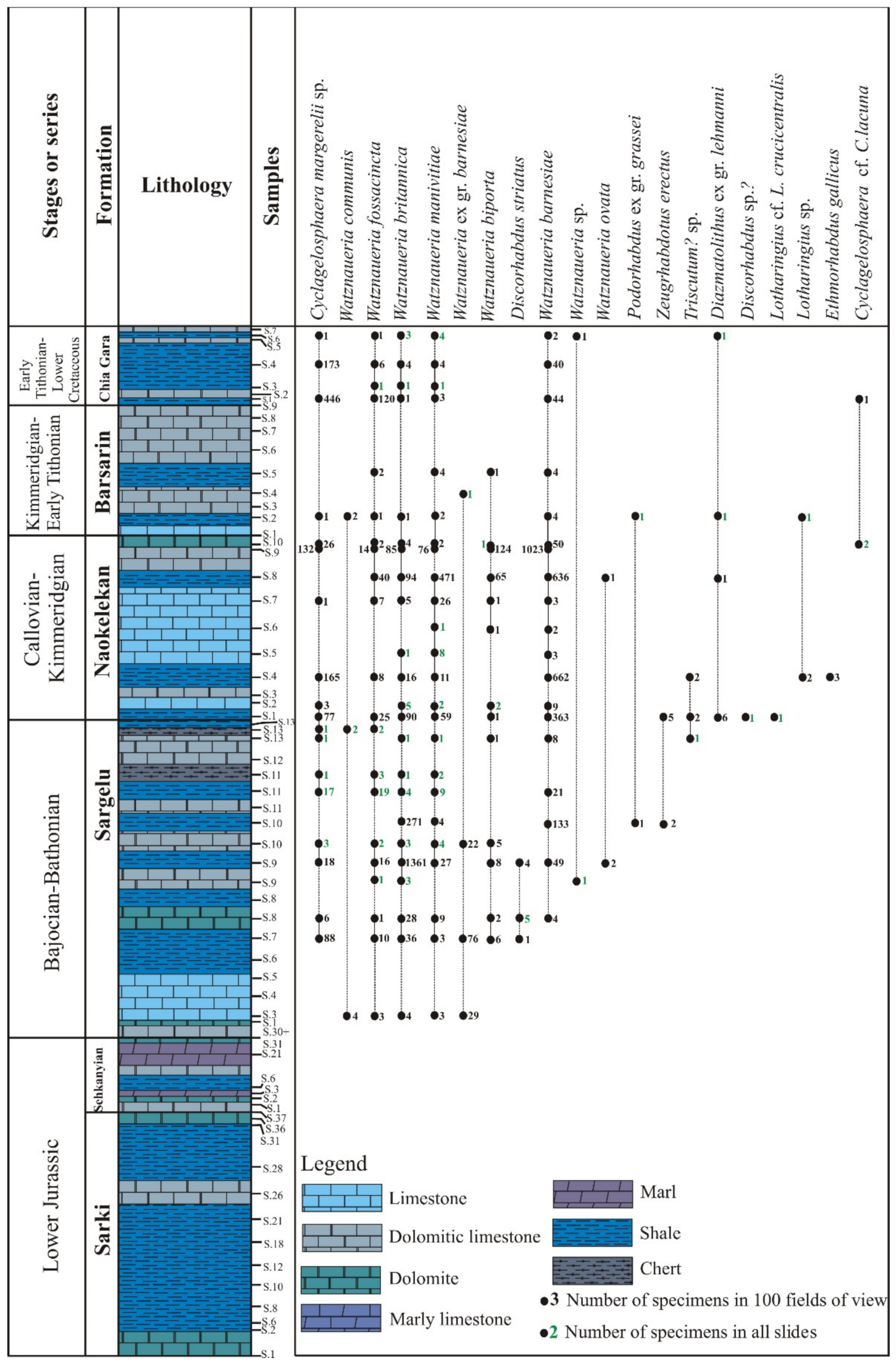

Figure 2. Sample location and distribution of the calcareous nannoplankton of the Warte section. 
Table 1. Simplified table showing the precise stratigraphic position of the studied samples from the Sarki, Sehkaniyan, Sargelu, Naokelekan, Barsarin and Chia Gara formations.

\begin{tabular}{|c|c|c|}
\hline Formation & Sample No. & Bed Thickness (m) \\
\hline Sarki & S 1 & 0.60 \\
\hline Sarki & S 2 & 0.20 \\
\hline Sarki & S 6 & 0.25 \\
\hline Sarki & S 8 & 0.15 \\
\hline Sarki & S 10 & 0.25 \\
\hline Sarki & S 12 & 0.20 \\
\hline Sarki & S 18 & 0.10 \\
\hline Sarki & S 21 & 0.30 \\
\hline Sarki & p.c. ${ }^{1}$ & 30.00 \\
\hline Sarki & S 26 & 5.00 \\
\hline Sarki & S 28 & 5.00 \\
\hline Sarki & S 31 & 7.50 \\
\hline Sarki & S 36 & 25.00 \\
\hline Sarki & S 37 & 4.00 \\
\hline Sehkanyian & $\mathrm{S} 1$ & 0.40 \\
\hline Sehkanyian & S 2 & 8.00 \\
\hline Sehkanyian & S 3 & 0.10 \\
\hline Sehkanyian & p.c. ${ }^{1}$ & 5.00 \\
\hline Sehkanyian & S 6 & 0.15 \\
\hline Sehkanyian & S 21 & 0.25 \\
\hline Sehkanyian & S 30 & 25.00 \\
\hline Sehkanyian & S 31 & 25.00 \\
\hline Sargelu & S 1 & 5.00 \\
\hline Sargelu & S 3 & 4.00 \\
\hline Sargelu & S 4 & 4.00 \\
\hline Sargelu & S 5 & 4.00 \\
\hline Sargelu & S 6 & 0.10 \\
\hline Sargelu & S 7 & 1.00 \\
\hline Sargelu & S 8 & 1.50 \\
\hline Sargelu & S 8 & 1.50 \\
\hline Sargelu & S 9 & 3.00 \\
\hline Sargelu & S 9 & 3.00 \\
\hline Sargelu & p.c. ${ }^{1}$ & 6.00 \\
\hline Sargelu & S 10 & 3.00 \\
\hline Sargelu & S 10 & 3.00 \\
\hline Sargelu & S 11 & 3.00 \\
\hline Sargelu & S 11 & 3.00 \\
\hline Sargelu & S 11 & 3.00 \\
\hline Sargelu & $\mathrm{S} 12$ & 1.00 \\
\hline Sargelu & S 13 & 2.00 \\
\hline Sargelu & S 13 & 2.00 \\
\hline Sargelu & S 13 & 6.00 \\
\hline Naokelekan & S 1 & 7.00 \\
\hline Naokelekan & $\mathrm{S} 2$ & 1.00 \\
\hline Naokelekan & S 3 & 1.80 \\
\hline Naokelekan & S 4 & 1.80 \\
\hline Naokelekan & S 5 & 1.80 \\
\hline Naokelekan & S 6 & 1.80 \\
\hline Naokelekan & S 7 & 1.80 \\
\hline Naokelekan & S 8 & 1.50 \\
\hline Naokelekan & S 9 & 1.50 \\
\hline Naokelekan & S 10 & 1.00 \\
\hline Barsarin & $\mathrm{S} 1$ & 6.00 \\
\hline Barsarin & S 2 & 6.00 \\
\hline Barsarin & S 3 & 2.00 \\
\hline Barsarin & S 4 & 3.00 \\
\hline
\end{tabular}


Table 1. Cont.

\begin{tabular}{ccc}
\hline Formation & Sample No. & Bed Thickness (m) \\
\hline Barsarin & S 5 & 3.00 \\
Barsarin & S 6 & 3.00 \\
Barsarin & S 7 & 5.00 \\
Barsarin & S 8 & 1.50 \\
Barsarin & S 9 & 1.50 \\
Chia Gara & S 1 & 1.43 \\
Chia Gara & S 2 & 1.43 \\
Chia Gara & S 3 & 1.43 \\
Chia Gara & S 4 & 1.43 \\
Chia Gara & S 5 & 1.43 \\
Chia Gara & S 6 & 1.43 \\
Chia Gara & S 7 & 1.43 \\
\hline
\end{tabular}

${ }^{1}$ p.c.: partly covered.

The calcareous nannofossils were investigated using optical methods. Initially, the rock samples were crushed and concentrated using a centrifuge, and smear slides $(24 \times 24 \mathrm{~mm})$ were prepared using Canada balsam. The slides were then analyzed under the microscope with a $1000 \times$ magnification for precise recognition and identification of the nannofossils present. At least 100 fields of view (diameter $0.018 \mathrm{~mm}$ ) were ob-served randomly in each slide (in a row-on-row pattern), in order to obtain relative abundances and semi quantitative information about the nannofossil assemblage composition. Species diversity of nannofossils was studied throughout the slide. Addi-tionally, the same samples were analyzed by XRF (X-ray fluorescence) to determine the both the major and trace element compositions. For each sample, $5 \mathrm{~g}$ of material was weighed and combined together with $1 \mathrm{~g}$ of wax and ground to homogeneity in an agate mortar. This was then pressed into a pellet for $60 \mathrm{~s}$ at $20 \mathrm{kbar}$ to prepare for trace element analysis. Measurements were performed in the Institut für Geowissenschaf-ten-Geologie, Bonn University. The isotopic geochemistry analyses for oxygen were conducted at the Ruhr-Universität Bochum, using a mass spectrometer MAT253 (Thermo Fisher Scientific, Bremen, Germany) equipped with a ConFlo IV and a GasBench II (both Thermo Fisher Scientific).

\section{Results}

\subsection{Lithological Analysis}

The Warte section, which formed the basis for this study, is located NE Iraq, where, to date, no detailed studies of the entire Jurassic have been attempted. A schematic lithological $\log$ was measured illustrating the transition from the Early-Jurassic-age Sarki Formation through to the Late Jurassic-Early Cretaceous-age Chia Gara Formation (see Figure 2). The measured profile is described from base to top, below.

\subsubsection{Sarki Formation}

The base of the profile referred to the lower part of the Sarki Formation $(31.95 \mathrm{~m})$. This generally consists of alternating beds of gray dolomite that are interbedded with dark grey-black shales. Individual dolomite beds range in thickness from c. 0.1 to $3.5 \mathrm{~m}$, whilst the shales range in thickness from c. 0.05 to $0.5 \mathrm{~m}$. Individual dolomite beds are generally medium-to-very-thickly bedded (Figure 3a). Bed boundaries are horizontal and often sharp and are laterally continuous across the outcrop. Internally, some beds show evidence of sedimentary structures, such as lamination, as well as evidence of tectonic deformation in the form of boudinage structures, fractures and joints (Figure 3b). The middle interval $(30 \mathrm{~m})$ of the formation is not well exposed and partly covered. 


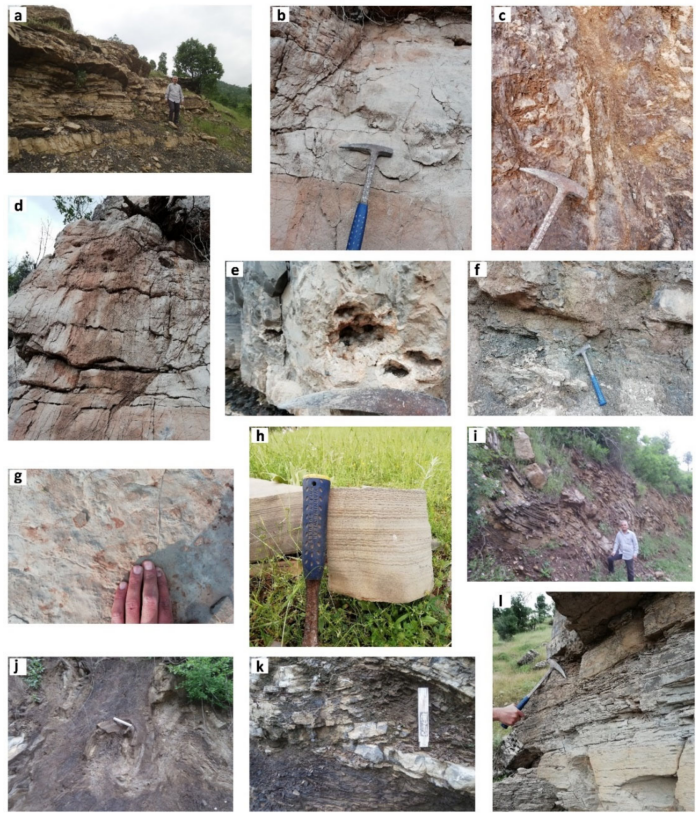

Figure 3. (a) Dolomite beds interbedded with dark grey-black shales in the lower part of the Sarki Formation. (b) Evidence of tectonic deformation in the form of fractures and joints within the Sarki Formation. (c) Veins filled with white calcite within the dolomite beds of the Sarki Formation. (d) Highly fractured dolomite beds of the Sehkaniyan Formation. (e) Quartz geodes within the upper part of the Sehkaniyan Formation. (f) Dolomite beds alternate with limestones and shales in the lower part of the Sargelu Formation. (g) A few ammonites within the Naokelekan Formation. (h) Common stromatolitic structure including stylolite (pressure solution) within the limestone of the contact area between the Naokelekan Formation and the overlying Barsarin Formation. (i) Minor folds in the contact area between the Naokelekan Formation and the overlying Barsarin Formation. (j) Tectonic deformation in the form of box folding within the Barsarin Formation. (k) The contact area between the Barsarin Formation and the overlying Chia Gara Formation. (1) Fissile shales interbedded with dolomitic limestones in the lower part of the Chia Gara Formation. Scales included.

Above the covered interval is the upper part of the formation $(119 \mathrm{~m})$, which predominantly comprises dolomites with $9 \mathrm{~m}$ of dolomitic limestones and $11 \mathrm{~m}$ of shales. Individual dolomite beds, which are grey in color, range from 10 to $50 \mathrm{~m}$ in thickness. The dolomites are very thickly bedded; some parts of the beds are cavernous with the presence of veins filled with white calcite (Figure 3c). Bed boundaries are horizontal and often sharp. Internally, some beds show evidence of sedimentary structures, such as hummocky cross stratification, while diagenetic features include liesegang rings and tectonic fractures were also noted. The uppermost bed of the Sarki Formation, i.e., the contact area with the overlying Sehkaniyan Formation, comprises $4 \mathrm{~m}$ of marly limestone. It is beige to yellow in color and highly fractured.

\subsubsection{Sehkaniyan Formation}

The lower part of the Sehkaniyan Formation (12.4 m thick) consists of grey dolomites interbedded with marls and one single dolomitic limestone bed. Individual dolomite beds are highly fractured, laminated and cross laminated, ranging in thickness from c. 0.4 to $7.9 \mathrm{~m}$, whilst the marl is c. $0.1 \mathrm{~m}$ thick (Figure $3 \mathrm{~d}$ ). The middle interval $(5 \mathrm{~m})$ of the formation is not well exposed and partly covered. The upper part of the formation $(455.85 \mathrm{~m})$, overlying the covered interval, comprises dolomites with $0.15 \mathrm{~m}$ shale and $0.25 \mathrm{~m}$ marl. The dolomites are grey to black in color, very thickly bedded and range from 3.85 to $70 \mathrm{~m}$ in thickness. The individual beds are horizontally bedded, with sharp bed boundaries. Deformation, in the form of fracturing and jointing, was noted, with some of the fractures infilled with calcite. Small $(2-5 \mathrm{~cm})$ quartz geodes were also noted (Figure 3e). 
The uppermost bed of the Sehkanyian Formation (50 m thick) is dolomite, and it marks the gradational contact between the Sehkanyian and Sargelu formations.

\subsubsection{Sargelu Formation}

The lower part of the formation (33 m thick) comprises thickly bedded, brown-colored dolomites, alternating with medium bedded, black-colored limestones, shales and a $3 \mathrm{~m}$ thick dolomitic limestone (Figure 3f). Individual dolomite beds are c. 1 to $5 \mathrm{~m}$ in thickness, limestone beds are c. $4 \mathrm{~m}$, whilst the shales are c. 0.1 to $3 \mathrm{~m}$ thick. The limestones are organic and bituminous with the presence of calcite veins. The middle interval $(6 \mathrm{~m})$ of the formation is not well exposed and partly covered. The upper part of the formation $(23 \mathrm{~m})$ consists of dark-brown-to-black dolomitic limestones, alternating with shales and two bands of chert. Individual dolomitic limestone beds are c. 2 to $4 \mathrm{~m}$ in thickness, shales are c. 1 to $4 \mathrm{~m}$, whilst the two bands of chert are c. 2 to $3 \mathrm{~m}$ thick. Internally, there is no evidence of any sedimentary structures except the dolomitic limestones, which may be laminated. Evidence of deformation, in the form of calcite veins, are present in the dolomitic limestones. The contact with the overlying Naokelekan Formation is gradational.

\subsubsection{Naokelekan Formation}

The Naokelekan Formation ( $27 \mathrm{~m}$ thick) consists of shales alternating with very thickly bedded limestones and dark-brown-colored dolomitic limestones, while the uppermost bed of the formation is a dark brown dolomite. The shales are c. 2 to $6 \mathrm{~m}$ thick; limestone beds are c. 2 to $3 \mathrm{~m}$ in thickness with c. 1.5 to $3 \mathrm{~m}$ thick dolomitic limestone beds. Both the dolomitic limestones and limestones are organic rich and occasionally mottled. They also contain rare ammonites, preserved as isolated specimens in the middle of the beds (Figure 3g). The dolomitic limestones and limestones include secondary calcite nodules and stylolites, with some beds showing liesegang rings. The sharp contact (6 m thick) between the Naokelekan Formation and the overlying Barsarin Formation is marked by the presence of very thickly bedded, stromatolitic limestones (Figure 3h). The contact area is also marked by the presence of minor folds due to post-depositional deformation in the area (as noted earlier; Figure 3i).

\subsubsection{Barsarin Formation}

The Barsarin Formation ( $25 \mathrm{~m}$ thick) consists of shales alternating with dark gray dolomitic limestones, and a $6 \mathrm{~m}$ thick limestone bed. The shales range in thickness from c. 3 to $6 \mathrm{~m}$, while the dolomitic limestone beds are c. 2 to $5 \mathrm{~m}$ thick. Due to tectonic deformation, the studied formation is highly fractured and folded (e.g., box folding; Figure 3j). The contact with the overlying Chia Gara Formation is sharp (Figure 3k).

\subsubsection{Chia Gara Formation}

The formation (10 $\mathrm{m}$ thick) consists of fissile shales interbedded with dolomitic limestones. The studied part of the profile represents the lower part of the Chia Gara Formation which is Late Jurassic-Early Cretaceous in age (Figure 31).

\subsection{Calcareous Nannofossils}

Sixty-five samples were collected from the Warte section and investigated using optical microscopy to determine the calcareous nannofossil biostratigraphy. The entire profile was sampled, with sample spacing being closer in the areas coinciding with the formation boundaries (i.e., Sarki/Sehkanyian, Sehkanyian/Sargelu, Sargelu/Naokelekan, Naokelekan/Barsarin, and Barsarin/Chia Gara).

Calcareous nannofossils are not very abundant in the samples, and those that are present tend to be moderately to poorly preserved (Figures 2 and 4). Despite this, calcareous nannofossils were recovered from four of the formations, with the exception of the Sarki and Sehkanyian formations that were barren. 


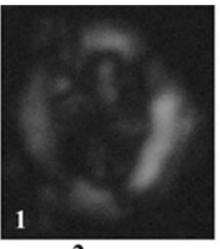

$2 \mu \mathrm{M}$

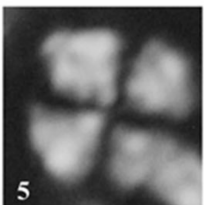

$2 \mu \mathrm{M}$

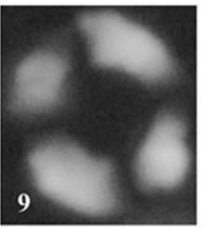

$2 \mu \mathrm{M}$

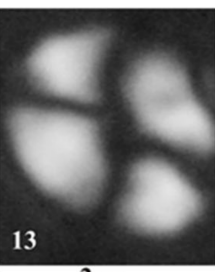

$2 \mu \mathrm{M}$

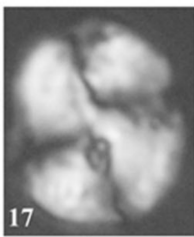

$\underline{2 \mu \mathrm{M}}$

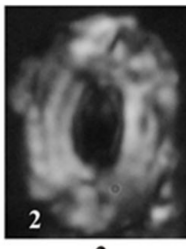

$\underline{2 \mu \mathrm{M}}$

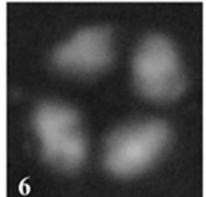

$2 \mu \mathrm{M}$

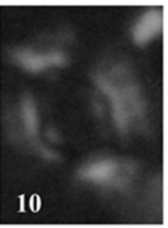

$2 \mu \mathrm{M}$

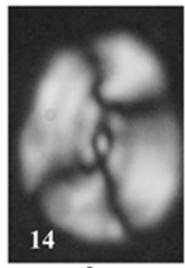

$2 \mu \mathrm{M}$

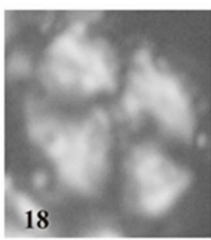

$2 \mu \mathrm{M}$

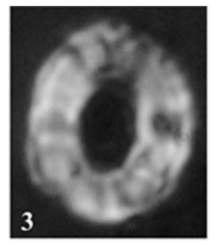

$\underline{2 \mu \mathrm{M}}$

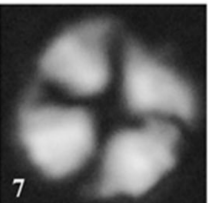

$2 \mu \mathrm{M}$

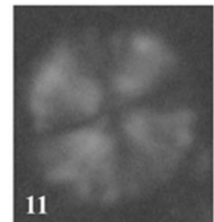

$2 \mu \mathrm{M}$

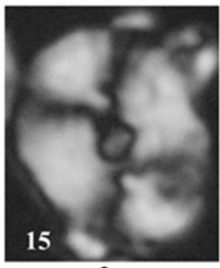

$2 \mu \mathrm{M}$

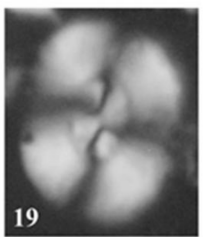

$\underline{2 \mu \mathrm{M}}$

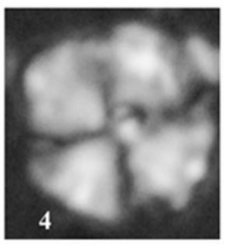

$2 \mu \mathrm{M}$

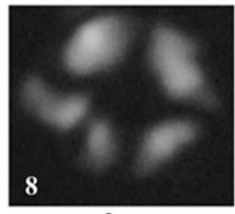

$2 \mu \mathrm{M}$

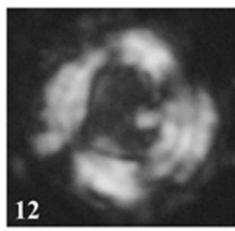

$2 \mu \mathrm{M}$

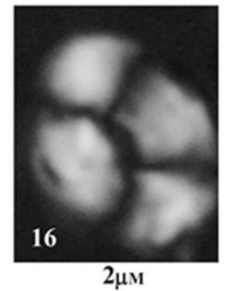

$2 \mu \mathrm{M}$

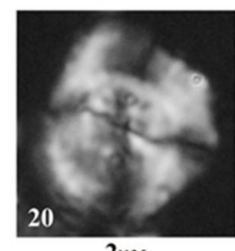

$\underline{2 \mu \mathrm{M}}$

Figure 4. Jurassic species of the Warte section. Abbreviation 'pol' denote polarized light. (1) Lotharingius ex gr. crucicentralis (Medd, 1971), pol. Naokelekan Formation, sample S.1. (2) Triscutum sp., pol. Naokelekan Formation, sample S.1. (3) Triscutum sp., pol. Naokelekan Formation, sample S.1. (4) Cyclagelosphaera margerelii Noël, 1965, pol.; Naokelekan Formation, sample S.1. (5) Cyclagelosphaera margerelii Noël, 1965, pol.; Chia Gara Formation, sample S.1. (6) Cyclagelosphaera ex gr. lacuna Varol and Girgis 1994, pol. Naokelekan Formation, sample S.10. (7) Cyclagelosphaera sp., pol. Naokelekan Formation, sample S.1. (8) Diazomatolithus lehmanii Noël, 1965, pol. Barsarin Formation, sample S.2. (9) Diazomatolithus ex gr. lehmanii Noël, 1965, pol. Naokelekan Formation, sample S.8. (10) Biscutum sp., pol. Naokelekan Formation, sample S.1. (11) Discorhabdus striatus Moshkovitz and Ehrlich, 1976, pol. Sargelu Formation, sample S.9., shale. (12) Podorhabdus ex gr. grassei Noël, 1965, pol. Barsarin Formation, sample S. 2. (13) Watznaueria barnesiae (Black in Black \& Barnes, 1959) Perch-Nielsen, 1968, pol. Naokelekan Formation, sample S.1. (14) Watznaueria Britannica (Stradner, 1963) Reinhardt, 1964, pol.; Naokelekan Formation, sample S.10. (15) Watznaueria Britannica (Stradner, 1963) Reinhardt, 1964, pol.; Naokelekan Formation, sample S.2. (16) Watznaueria fossacincta (Black, 1971) Bown in Bown and Cooper, 1989, pol. Naokelekan Formation, sample S.2. (17) Watznaueria communis Reinhardt 1964, pol.: Naokelekan Formation, sample S.2. (18) Watznaueria communis Reinhardt 1964, pol.: Naokelekan Formation, sample S.2. (19) Watznaueria biporta Bukry, 1969, pol.: Naokelekan Formation, sample S.2. (20) Watznaueria manivitiae Bukry, 1973, pol. Barsarin Formation, sample S.2. 
The nannofossil assemblage identified from the Sargelu, Naokelekan, Barsarin and Chia Gara formations is dominated by the genus Watznaueria (Figure 5). Indeed, five species could be recognized, and these varied markedly in terms of their abundance. The percentages of $W$. barnesiae and $W$. fossacincta range from $0.12 \%$ to $33 \%$ and together they comprise $42 \%$ of the entire assemblage. The percentages of W. britannica and W. manivitiae range from $0.8 \%$ up to $67 \%$ and $63 \%$, respectively. The percentage of Cyclagelosphaera margerelii ranges from $0.1 \%$ to $38 \%$ of the total assemblage.

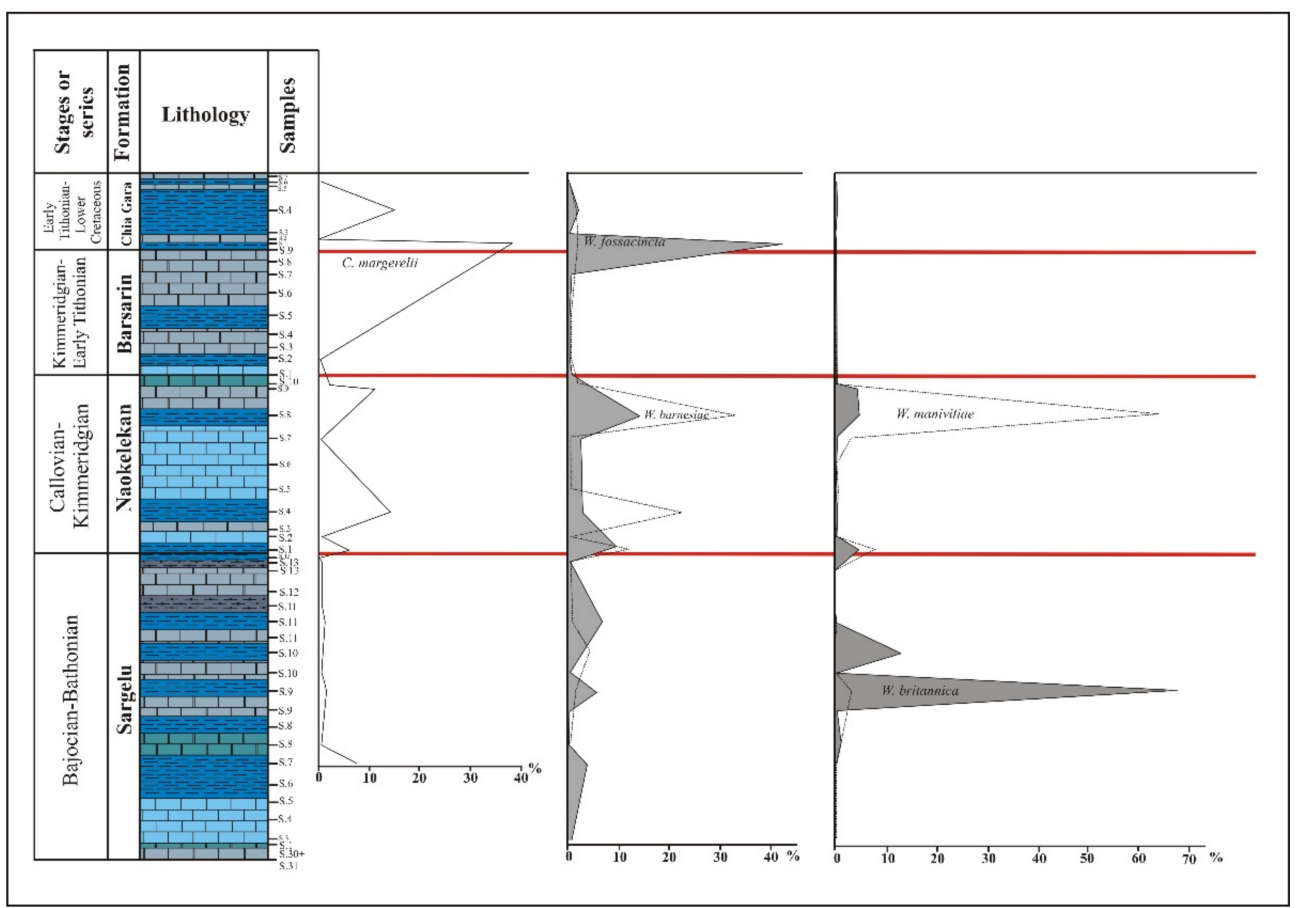

Figure 5. Percentage of the nannofossil Cyclagelosphaera magrerelii and Watznaueria species of the Warte section.

The mudstones and shales of the Sargelu Formation show three distinct abundance peaks for $W$. fossacincta and two peaks for W. britannica (Figure 5). Nannofossil assemblage of this formation is most diverse, with biodiversity being significantly reduced in the limestones and dolomitic limestones of the Sargelu, Naokelekan, Barsarin and Chia Gara formations (Figures 2 and 5).

All of the identified species are characterized by very long stratigraphic ranges, extending from the mid-to-late Jurassic (at least). In addition, these species also show a wide geographical distribution. This, together with the lack of precise zonal markers in the Warte profile, makes it difficult to determine the presence or absence of precise nannofossil zones. However, the nannofossils can provide valuable information with regard to ambient oceanic paleotemperatures and the paleoenvironment of the surface waters.

\subsection{Geochemistry}

Sixty-five samples were collected from the Warte section covering the complete sedimentary succession that is represented by the Sarki, Sehkanyian, Sargelu, Naokelekan, Barsarin and Chia Gara formations. The samples were prepared and analyzed for oxygen stable isotopic geochemistry and trace elements.

\subsubsection{Oxygen Isotope Analysis}

A total of 65 samples, encompassing all of the formations, were collected for isotopic analysis. At the base of the profile, the Early-Jurassic-age Sarki Formation shows a slightly positive oxygen isotope $\left(\delta^{18} \mathrm{O}\right)$ value $(0.13 \%$; indeed, this is the only positive value recorded 
from the profile), while the values from the rest of the formation vary between $-0.65 \%$ and $-6.99 \%$. The overlying Early-Jurassic-age Sehkanyian Formation values fluctuate between $-0.29 \%$ and $-10.07 \%$, but are all negative. The samples from the Middle-Jurassic-age Sargelu Formation continue this negative trend (ranging from $-2.27 \%$ to $-6.57 \%$ ). One sample from the latter formation did not provide a good value (Table 2).

Table 2. Oxygen isotope $\left({ }^{18} \mathrm{O}\right)$ and carbon isotope $\left({ }^{13} \mathrm{C}\right)$ data for the samples from the Sarki, Sehkaniyan, Sargelu, Naokelekan, Barsarin and Chia Gara formations.

\begin{tabular}{|c|c|c|c|}
\hline Formation & Sample No. & $\delta^{18} O$ & $\delta^{13} C$ \\
\hline Sarki & S1 & 0.13 & -0.76 \\
\hline Sarki & S2 & -1.03 & -0.52 \\
\hline Sarki & S6 & -0.97 & -0.80 \\
\hline Sarki & S8 & -2.24 & -1.23 \\
\hline Sarki & $\mathrm{S} 10$ & -1.50 & -1.43 \\
\hline Sarki & $\mathrm{S} 12$ & -1.86 & -1.08 \\
\hline Sarki & $\mathrm{S} 18$ & -2.11 & -1.49 \\
\hline Sarki & $\mathrm{S} 21$ & -1.56 & -1.95 \\
\hline Sarki & $\mathrm{S} 26$ & -6.99 & -3.47 \\
\hline Sarki & $\mathrm{S} 28$ & -3.22 & 0.99 \\
\hline Sarki & $\mathrm{S} 31$ & -1.70 & -3.66 \\
\hline Sarki & S36 & -1.28 & -3.05 \\
\hline Sarki & S37 & -0.65 & -2.02 \\
\hline Sehkanyian & $\mathrm{S} 1$ & -10.07 & -3.27 \\
\hline Sehkanyian & S2 & -1.23 & -5.03 \\
\hline Sehkanyian & S3 & -4.48 & -5.46 \\
\hline Sehkanyian & S6 & -0.29 & -0.70 \\
\hline Sehkanyian & S21 & -7.29 & -7.38 \\
\hline Sehkanyian & $\mathrm{S} 30$ & -2.67 & -0.95 \\
\hline Sehkanyian & $\mathrm{S} 31$ & -3.34 & -0.89 \\
\hline Sargelu & $\mathrm{S} 1$ & -3.42 & -3.02 \\
\hline Sargelu & S3 & -4.15 & -2.68 \\
\hline Sargelu & $\mathrm{S} 4$ & -5.06 & 0.03 \\
\hline Sargelu & S5 & -4.25 & -0.03 \\
\hline Sargelu & S6 & -4.00 & -3.30 \\
\hline Sargelu & S7 & -4.91 & -0.99 \\
\hline Sargelu & S8 & -2.27 & -1.76 \\
\hline Sargelu & S8 & -3.64 & -1.21 \\
\hline Sargelu & S9 & -2.84 & -0.49 \\
\hline Sargelu & S9 & -5.28 & -2.84 \\
\hline Sargelu & $\mathrm{S} 10$ & -3.38 & -5.82 \\
\hline Sargelu & $\mathrm{S} 10$ & -4.92 & -1.94 \\
\hline Sargelu & S11 & -6.57 & -3.34 \\
\hline Sargelu & S11 & -4.92 & -3.34 \\
\hline Sargelu & $\mathrm{S} 11$ & i.s. ${ }^{1}$ & i.s. ${ }^{1}$ \\
\hline Sargelu & $\mathrm{S} 12$ & -4.21 & -4.14 \\
\hline Sargelu & $\mathrm{S} 13$ & -5.55 & -4.00 \\
\hline Sargelu & $\mathrm{S} 13$ & -3.18 & -3.64 \\
\hline Sargelu & $\mathrm{S} 13$ & -3.70 & -4.44 \\
\hline Naokelekan & S1 & -2.22 & -3.31 \\
\hline Naokelekan & S2 & -4.64 & -5.81 \\
\hline Naokelekan & S3 & -5.03 & -5.82 \\
\hline Naokelekan & $\mathrm{S} 4$ & -4.06 & -4.26 \\
\hline Naokelekan & S5 & -6.82 & -3.73 \\
\hline Naokelekan & S6 & -4.26 & -3.76 \\
\hline Naokelekan & S7 & -3.46 & -5.49 \\
\hline Naokelekan & S8 & -3.70 & -1.61 \\
\hline Naokelekan & S9 & -4.25 & -4.20 \\
\hline Naokelekan & $\mathrm{S} 10$ & -0.99 & -6.49 \\
\hline
\end{tabular}


Table 2. Cont.

\begin{tabular}{cccc}
\hline Formation & Sample No. & $\boldsymbol{\delta}^{\mathbf{1 8}} \mathbf{O}$ & $\boldsymbol{\delta}^{\mathbf{1 3}} \mathbf{C}$ \\
\hline Barsarin & S1 & -3.54 & -9.87 \\
Barsarin & S2 & -4.01 & -9.19 \\
Barsarin & S3 & -7.77 & -9.97 \\
Barsarin & S4 & -4.65 & -11.31 \\
Barsarin & S5 & -5.24 & -9.69 \\
Barsarin & S6 & -3.94 & -10.40 \\
Barsarin & S7 & -4.24 & -10.33 \\
Barsarin & S8 & -4.25 & -10.60 \\
Barsarin & S9 & -4.12 & -9.49 \\
Chia Gara & S1 & -5.70 & -4.70 \\
Chia Gara & S2 & -5.36 & -6.04 \\
Chia Gara & S3 & -4.60 & -8.21 \\
Chia Gara & S4 & -5.39 & -4.91 \\
Chia Gara & S5 & -3.67 & -10.65 \\
Chia Gara & S6 & -4.27 & -11.18 \\
Chia Gara & S7 & -2.13 & -9.14 \\
\hline
\end{tabular}

${ }^{1}$ i.s.: insufficient signal.

Moving up profile, the samples from the Late-Jurassic-age Naokelekan and Barsarin formations show consistently negative oxygen isotope $\left(\delta^{18} \mathrm{O}\right)$ values (range from $-0.99 \%$ to $-6.82 \%$ in the Naokelekan Formation, and from $-3.54 \%$ to $-7.77 \%$ in the Barsarin Formation). The overlying Late Jurassic-Early Cretaceous-age Chia Gara Formation values are also all negative, and fluctuate between $-2.13 \%$ and $-5.70 \%$ (Table 2). However, before starting to study and interpret the oxygen isotope $\left({ }^{18} \mathrm{O}\right)$ data, it is necessary to know the extent to which the sediments of the Sarki, Sehkanyian, Sargelu, Naokelekan, Barsarin and Chia Gara formations were influenced by diagenesis. The oxygen isotopes are very sensitive to the diagenetic processes [33] due to the large thermal breakdown of the oxygen isotopes; therefore, the oxygen isotope values were used to indicate ancient water temperatures as they are strongly influenced by water temperature [34,35]. Other authors have suggested that the relationship between the carbon and oxygen isotope values can be used to estimate the influence of diagenesis on the sediments and the extent to which the oxygen isotopes represent the initial imprint of the environment in which these sediments were deposited [33,36,37]. According to these authors, the relationship between the carbon and oxygen isotope values, which is positive and strong, indicates that the oxygen isotopes were strongly influenced by diagenesis as a result of the leakage and transfer of solutions bearing light oxygen and carbon from the diagenetic solutions, such as atmospheric water, whilst weak or negative relationship indicates that the oxygen isotopes were not influenced by diagenesis. Indeed, the relationship established in this study registered weak correlation $\left(R^{2}=0.0943\right)$ between the carbon and oxygen isotope values. This would indicate, as noted above, that the Sarki, Sehkanyian, Sargelu, Naokelekan, Barsarin and Chia Gara sediments were not or weakly influenced by diagenesis, and thus, the oxygen isotope values represent their initial imprint in the sediments from the Warte section.

\subsubsection{Inorganic Geochemistry}

Sixty-five samples were collected from the six formations of the Warte section, and then analyzed for their trace elements. Several elemental ratios were calculated and used for paleoclimate and paleoecological interpretations. The latter, including $\mathrm{Ca}, \mathrm{Al}, \mathrm{Rb} / \mathrm{Sr}$, $\mathrm{Sr} / \mathrm{Cu}$ and $\mathrm{Sr} / \mathrm{Ba}$, are considered by many authors to be good paleoclimate proxies [38-41]. Furthermore, the trace element $\mathrm{Sr}$ is considered to be a useful salinity indicator [15,42-44].

The Ba values for the samples from the Early-Jurassic-age Sarki Formation fluctuate between 3 and $133 \mathrm{ppm}$, while the $\mathrm{Cu}$ values range from 2.2 to $56.6 \mathrm{ppm}$. The $\mathrm{Sr}$ values vary between 53 and $285 \mathrm{ppm}$, with the $\mathrm{Rb}$ values ranging from 1.0 to $18.4 \mathrm{ppm}$. The samples from the Sarki Formation also showed variable ranges for $\mathrm{Ca}(4.4-30.96 \%)$ and $\mathrm{Al}$ $(0.08-5.93 \%)$. 
The samples from the Early-Jurassic-age Sehkanyian Formation show some fluctuations for $\mathrm{Ba}$ (5-108 ppm), with the values for $\mathrm{Cu}(5.2-17.6 \mathrm{ppm})$ being lower than those of the Sarki Formation, while the Sr values vary between 62 and $137 \mathrm{ppm}$, and the Rb values range from 0.9 to $10.7 \mathrm{ppm}$. The ranges for $\mathrm{Ca}(8.85-24.46 \%)$ and $\mathrm{Al}(0.15-4.03 \%)$ were also variable.

The Ba values for the samples from the Middle-Jurassic-age Sargelu Formation fluctuate between 3 and 586 ppm (values that are considerably higher than the underlying formation). The values for $\mathrm{Cu}(3.7-87 \mathrm{ppm})$ are also higher than those measured for the underlying formation, with the Sr values ranging between 46 and 445 ppm being higher than those of the Sehkanyian Formation. The $\mathrm{Rb}$ values from the same formation that range from 0.4 to $51.8 \mathrm{ppm}$, are almost five times higher. The ranges of $\mathrm{Ca}(1.55-35.11 \%)$ and $\mathrm{Al}$ $(0.03-4.71 \%)$ were also measured.

The Late Jurassic-age Naokelekan Formation shows some fluctuations for Ba (18.4-287 ppm), which are considerably lower than those of the underlying formation, while the amounts of $\mathrm{Cu}$ (4.51-61.4 ppm), $\mathrm{Sr}(145-504 \mathrm{ppm})$ and $\mathrm{Rb}(0.5-42.5 \mathrm{ppm})$ were also measured. The samples from the Naokelekan Formation also showed variable ranges for $\mathrm{Ca}(16.78-34.78 \%)$ and $\mathrm{Al}(0.04-4.18 \%)$.

The Ba values for the samples from the Late-Jurassic-age Barsarin Formation fluctuate between 7 and 649 ppm (values that are considerably higher than those of the underlying formation), with the values for $\mathrm{Cu}(1.2-11.2 \mathrm{ppm}$ ) being lower than those of the Naokelekan Formation. In contrast, the highest values for Sr (147.3-1007 ppm) are more than twice those measured for the underlying formation, while the maximum $\mathrm{Rb}$ values (0.3-7.2 ppm) are almost five times lower. The amounts of $\mathrm{Ca}(31.34-38.66 \%)$ recorded from the Barsarin Formation are consistently within the $30-40 \%$ range. The values for $\mathrm{Al}(0.04-0.71 \%)$, meanwhile, are low.

The samples from the Late Jurassic-Early Cretaceous-age Chia Gara Formation show some fluctuations for $\mathrm{Ba}(2-112 \mathrm{ppm})$ (values that are considerably lower than those of the underlying formation), whilst the $\mathrm{Cu}$ values (1.1-92.1 ppm) are higher than those of the Barsarin Formation. Sr values from the same formation vary from 274 to 1088 ppm, with the $\mathrm{Rb}$ values (1-52.9 ppm) being almost five times higher. The samples from the Chia Gara Formation also showed various ranges for $\mathrm{Ca}(15.67-36.73 \%)$ and $\mathrm{Al}(0.19-8.12 \%)$.

\section{Discussion}

The Lower Jurassic to Lower Cretaceous of Northern Iraq (Warte area) comprises six lithological units, namely, the Sarki, Sehkanyian, Sargelu, Naokelekan, Barsarin and Chia Gara formations. These formations represent the transition from the Early Jurassic (Sarki Formation) through to the Late Jurassic-Early Cretaceous (Chia Gara Formation). Lithologically, the Warte section succession comprises interbedded carbonates and shales with rare cherts. The carbonates, originally limestones, have since been wholly or partially altered to dolomites, particularly in the Sarki and Sehkanyian formations.

The following discussion investigates a few important points related to the successions, namely, their calcareous nannofossil biostratigraphy, paleoecology and paleoclimate conditions that prevailed during the Early Jurassic-Early Cretaceous of Northern Iraq.

\subsection{Calcareous Nannofossil Biostratigraphy}

As mentioned above, calcareous nannofossils are moderately to poorly preserved throughout the investigated interval, and thus, the precise determination of the ages of the various formation boundaries was not possible. This was due to the absence of specific age markers, for example, Cyclagelosphaera weidmanni Reale and Monechi. This species, absent from the studied section, is a marker species of the Middle Jurassic-Upper Jurassic boundary as it only common in the Callovian of the Tethys Realm [45]. Moreover, Nannoconus steinmannii subsp. minor Deres and Achéritéguy, which was also not found in the studied section, is the marker species for the Jurassic-Cretaceous boundary. Indeed, the species is considered to be the characteristic species of the Lower Cretaceous of the Tethys Realm [46,47]. 
Despite the lack of specific age markers noted above, some markers were recovered. For example, in the upper part of the Sargelu Formation, Cyclagelosphaera margerelii, Watznaueria britannica, W. fossacincta and W. manivitiae were all recorded for the first time. These species are indicative of the Bajocian Stage [45]. Furthermore, Watznaueria barnesiae indicative of the Bathonian Stage was also recovered $[48,49]$. In addition, the first occurrence of Watznaueria ovata is indicative of the Callovian Stage $[48,50,51]$. Thus, the age range for the Sargelu Formation is clearly Bajocian-Callovian.

\subsection{Paleoclimate Proxies}

As noted above, a range of geochemical proxies were measured from the various formations from NE Iraq in order to provide information about the paleoclimate at the time of deposition. The proxies used include $\mathrm{Ca}, \mathrm{Al}, \mathrm{Sr} / \mathrm{Ba}, \mathrm{Rb} / \mathrm{Sr}$ and $\mathrm{Sr} / \mathrm{Cu}$ (Table 3 and Figure 6) [38-40].

Table 3. Trace (in ppm) element concentrations, including geochemical proxies for paleoclimate conditions, $\mathrm{Ca}, \mathrm{Al}, \mathrm{Sr} / \mathrm{Ba}, \mathrm{Rb} / \mathrm{Sr}$ and $\mathrm{Sr} / \mathrm{Cu}$, for the samples from the Sarki, Sehkaniyan, Sargelu, Naokelekan, Barsarin and Chia Gara formations.

\begin{tabular}{|c|c|c|c|c|c|c|c|c|c|c|}
\hline Formation & Sample No. & Ba (ppm) & $\mathrm{Cu}(\mathrm{ppm})$ & Sr (ppm) & Rb (ppm) & $\mathrm{Ca}(\%)$ & Al (\%) & $\mathrm{Sr} / \mathrm{Cu}$ & $\mathrm{Sr} / \mathrm{Ba}$ & $\mathrm{Rb} / \mathrm{Sr}$ \\
\hline Sarki & S1 & 4 & 4.3 & 87 & 6.8 & 17.74 & 0.36 & 20.23 & 21.75 & 0.08 \\
\hline Sarki & S2 & 7 & 6.2 & 77 & 10.2 & 17.01 & 0.94 & 12.42 & 11 & 0.13 \\
\hline Sarki & S6 & 103 & 18.8 & 102 & 10.1 & 6.21 & 4.83 & 5.43 & 0.99 & 0.09 \\
\hline Sarki & S8 & 122 & 24 & 96 & 18.4 & 4.91 & 5.27 & 4.00 & 0.79 & 0.19 \\
\hline Sarki & S10 & 30 & 9.4 & 105 & 9.3 & 14.35 & 1.49 & 11.17 & 3.50 & 0.09 \\
\hline Sarki & S12 & 8 & 3.2 & 113 & 11.3 & 17.06 & 0.95 & 35.31 & 14.13 & 0.1 \\
\hline Sarki & S18 & 133 & 22.4 & 100 & 13.3 & 4.4 & 5.93 & 4.46 & 0.75 & 0.13 \\
\hline Sarki & S21 & 102 & 49.8 & 53 & 11.6 & 4.32 & 5.77 & 1.06 & 0.52 & 0.22 \\
\hline Sarki & S26 & 6.0 & 5.19 & 203.1 & 1.0 & 30.96 & 0.08 & 39.13 & 33.85 & 0.005 \\
\hline Sarki & S28 & 88 & 17.2 & 116 & 8.9 & 10.51 & 4.64 & 6.74 & 1.32 & 0.08 \\
\hline Sarki & S31 & 115 & 56.6 & 285 & 12.8 & 15.32 & 2.02 & 5.04 & 2.48 & 0.04 \\
\hline Sarki & S36 & 3 & 2.2 & 79 & 2.5 & 21.26 & 0.21 & 35.91 & 26.33 & 0.03 \\
\hline Sarki & S37 & 24.9 & 12.28 & 61.1 & 3.3 & 14.49 & 0.22 & 4.98 & 2.45 & 0.05 \\
\hline Sehkanyian & S1 & 23 & 5.2 & 111 & 7.7 & 24.32 & 0.66 & 21.35 & 4.83 & 0.07 \\
\hline Sehkanyian & $\mathrm{S} 2$ & 7.2 & 4.93 & 108.3 & 0.9 & 17.69 & 0.25 & 21.97 & 15.04 & 0.008 \\
\hline Sehkanyian & S3 & 108 & 7.5 & 62 & 6.2 & 8.85 & 4.03 & 8.27 & 0.57 & 0.1 \\
\hline Sehkanyian & S6 & 74 & 13.2 & 82 & 9.1 & 8.87 & 3.35 & 6.21 & 1.11 & 0.11 \\
\hline Sehkanyian & S21 & 31 & 10.2 & 92 & 10.7 & 24.46 & 1.52 & 9.02 & 2.97 & 0.12 \\
\hline Sehkanyian & S30 & 6.2 & 14.92 & 101.5 & 2.0 & 17.60 & 0.15 & 6.80 & 16.37 & 0.02 \\
\hline Sehkanyian & S31 & 5 & 17.6 & 137 & 4.1 & 21.18 & 0.54 & 7.78 & 27.40 & 0.03 \\
\hline Sargelu & S1 & 3 & 18 & 112 & 1.7 & 21.86 & 0.29 & 6.22 & 37.33 & 0.02 \\
\hline Sargelu & S3 & 67 & 8.7 & 416 & 1.3 & 35.11 & 0.22 & 47.82 & 6.21 & 0.003 \\
\hline Sargelu & S4 & 5.0 & 10.39 & 164.4 & 0.9 & 31.57 & 0.11 & 15.82 & 32.88 & 0.005 \\
\hline Sargelu & S5 & 9 & 9.4 & 223 & 2.5 & 33.75 & 0.47 & 23.72 & 24.78 & 0.01 \\
\hline Sargelu & S6 & 65 & 10 & 367 & 2.9 & 31.19 & 0.23 & 36.70 & 5.65 & 0.008 \\
\hline Sargelu & S7 & 44 & 77.8 & 260 & 20.6 & 27.77 & 1.94 & 3.34 & 5.91 & 0.08 \\
\hline Sargelu & S8 & 23 & 50.7 & 194 & 8.9 & 22.17 & 1.38 & 3.83 & 8.43 & 0.05 \\
\hline Sargelu & S8 & 159 & 63.5 & 302 & 51.8 & 16.63 & 4.71 & 4.76 & 1.90 & 0.17 \\
\hline Sargelu & S9 & 24 & 27.4 & 286 & 9.5 & 30.35 & 1.44 & 10.44 & 11.92 & 0.03 \\
\hline Sargelu & S9 & 46 & 59.7 & 194 & 21.5 & 25.38 & 2.69 & 3.25 & 4.22 & 0.11 \\
\hline Sargelu & S10 & 586 & 5.8 & 317 & 5.2 & 32.97 & 0.55 & 54.66 & 0.54 & 0.02 \\
\hline Sargelu & S10 & 68 & 87 & 330 & 18.6 & 21.34 & 1.68 & 3.79 & 4.85 & 0.06 \\
\hline Sargelu & S11 & 7 & 14.3 & 46 & 8.7 & 1.55 & 0.15 & 3.22 & 6.57 & 0.19 \\
\hline Sargelu & S11 & 12 & 16 & 86 & 2 & 3.92 & 0.2 & 5.38 & 7.17 & 0.02 \\
\hline Sargelu & S11 & 38 & 54.6 & 445 & 16.5 & 19.66 & 1.37 & 8.15 & 11.71 & 0.04 \\
\hline Sargelu & S12 & 8 & 3.7 & 242 & 1.1 & 33.91 & 0.11 & 65.41 & 30.25 & 0.005 \\
\hline Sargelu & S13 & 139 & 41.5 & 293 & 21.1 & 18.79 & 1.68 & 7.06 & 2.11 & 0.07 \\
\hline Sargelu & S13 & 41.1 & 16.06 & 73.1 & 0.4 & 4.40 & 0.03 & 4.55 & 1.78 & 0.005 \\
\hline Sargelu & S13 & 77.5 & 14.34 & 256.9 & 1.6 & 21.23 & 0.12 & 17.91 & 3.31 & 0.006 \\
\hline Naokelekan & S1 & 140 & 56.5 & 251 & 30.7 & 16.78 & 2.2 & 4.44 & 1.79 & 0.12 \\
\hline Naokelekan & $\mathrm{S} 2$ & 89 & 16.1 & 399 & 5.9 & 34.05 & 0.42 & 24.78 & 4.48 & 0.01 \\
\hline Naokelekan & S3 & 23 & 7.2 & 145 & 2.7 & 34.78 & 0.22 & 20.14 & 6.30 & 0.02 \\
\hline Naokelekan & $\mathrm{S} 4$ & 124 & 44.3 & 504 & 18.1 & 27.75 & 1.29 & 11.38 & 4.06 & 0.04 \\
\hline
\end{tabular}


Table 3. Cont.

\begin{tabular}{|c|c|c|c|c|c|c|c|c|c|c|}
\hline Formation & Sample No. & Ba (ppm) & $\mathrm{Cu}(\mathrm{ppm})$ & Sr (ppm) & Rb (ppm) & $\mathrm{Ca}(\%)$ & Al (\%) & $\mathrm{Sr} / \mathrm{Cu}$ & $\mathrm{Sr} / \mathrm{Ba}$ & $\mathrm{Rb} / \mathrm{Sr}$ \\
\hline Naokelekan & S5 & 128.2 & 6.52 & 265.6 & 0.5 & 33.98 & 0.04 & 40.74 & 2.07 & 0.002 \\
\hline Naokelekan & S6 & 57 & 8.8 & 416 & 2.4 & 34.5 & 0.19 & 47.27 & 7.30 & 0.006 \\
\hline Naokelekan & S7 & 18.4 & 4.51 & 174.4 & 0.5 & 32.80 & 0.07 & 38.67 & 9.48 & 0.003 \\
\hline Naokelekan & S8 & 268 & 61.4 & 333 & 42.5 & 19.51 & 4.18 & 5.42 & 1.24 & 0.13 \\
\hline Naokelekan & S9 & 96.6 & 40.01 & 317.2 & 4.4 & 24.82 & 0.51 & 7.93 & 3.28 & 0.01 \\
\hline Naokelekan & S10 & 287 & 11.7 & 372 & 14.1 & 25.13 & 1.28 & 31.79 & 1.30 & 0.04 \\
\hline Barsarin & $\mathrm{S} 1$ & 649 & 1.2 & 446 & 1.1 & 38.07 & 0.16 & 371.67 & 0.69 & 0.002 \\
\hline Barsarin & $\mathrm{S} 2$ & 22 & 9.6 & 364 & 7.2 & 33.39 & 0.71 & 37.92 & 16.55 & 0.02 \\
\hline Barsarin & S3 & 27 & 5.5 & 1007 & 4.3 & 38.57 & 0.51 & 183.09 & 37.30 & 0.004 \\
\hline Barsarin & S4 & 4.2 & 4.23 & 241.4 & 0.5 & 33.16 & 0.05 & 57.07 & 57.48 & 0.002 \\
\hline Barsarin & S5 & 19 & 5.6 & 377 & 5.1 & 31.34 & 0.59 & 67.32 & 19.84 & 0.01 \\
\hline Barsarin & S6 & 7 & 4.2 & 269 & 2.5 & 38.66 & 0.46 & 64.05 & 38.43 & 0.009 \\
\hline Barsarin & S7 & 3.3 & 4.07 & 163.3 & 0.4 & 33.91 & 0.04 & 40.12 & 49.48 & 0.002 \\
\hline Barsarin & S8 & 4.0 & 3.02 & 147.3 & 0.3 & 33.50 & 0.04 & 48.77 & 36.83 & 0.002 \\
\hline Barsarin & S9 & 12 & 11.2 & 391 & 4.4 & 36.91 & 0.63 & 34.91 & 32.58 & 0.01 \\
\hline Chia Gara & S1 & 102 & 75.9 & 764 & 52.9 & 10.04 & 8.12 & 10.07 & 7.49 & 0.07 \\
\hline Chia Gara & S2 & 27 & 21.9 & 761 & 11.6 & 35.78 & 1.77 & 34.75 & 28.19 & 0.02 \\
\hline Chia Gara & S3 & 10 & 7.2 & 314 & 1.4 & 33.22 & 0.28 & 43.61 & 31.40 & 0.004 \\
\hline Chia Gara & $\mathrm{S} 4$ & 112 & 92.1 & 1088 & 51.7 & 15.67 & 6.79 & 11.81 & 9.71 & 0.05 \\
\hline Chia Gara & S5 & 25 & 7.8 & 274 & 5.5 & 36.73 & 0.94 & 35.13 & 10.96 & 0.02 \\
\hline Chia Gara & S6 & 54 & 58.3 & 549 & 22 & 25.61 & 3.39 & 9.42 & 10.17 & 0.04 \\
\hline Chia Gara & S7 & 2 & 1.1 & 321 & 1 & 30.06 & 0.19 & 291.82 & 160.50 & 0.003 \\
\hline
\end{tabular}

The inverse relationship between the $\mathrm{Ca}$ and $\mathrm{Al}$ contents has been used by a range of authors as a proxy for both salinity and/or aridity $[15,41]$. In general, the values measured from the various formations show an overall increase in Ca content (e.g., 15.32, 25.13, 38.66), moving up through the stratigraphy (i.e., from the basal Sarki Formation through to the Chia Gara Formation at the top) with a corresponding decrease in Al content (e.g., 2.02, $1.28,0.46$ ) (see Table 3). The increase in $\mathrm{Ca}$ and the corresponding decrease in Al would suggest that deposition occurred under arid conditions [17,41]. Interestingly, a recent study on the petrography and geochemistry of the Middle-Upper Jurassic Banik section from northernmost Iraq (a region that is located close to the northwestern boundary of the Warte section) suggested that the deposition of the Middle-Upper Jurassic formations occurred under arid conditions [17]. This conclusion was based on the results obtained from selected geochemical proxies for evaporitic conditions, including the inverse relationship between the $\mathrm{Ca}$ and $\mathrm{Al}$ contents.

The high $\mathrm{Sr} / \mathrm{Ba}$ ratio values were also interpreted in terms of salinity and/or aridity [40]. According to Wang et al. (2017), high Sr/Ba ratio values can indicate high salinity and/or arid climates, whilst low $\mathrm{Sr} / \mathrm{Ba}$ ratio values suggest low salinity and/or humid climates. Relatively high values of $\mathrm{Sr} / \mathrm{Ba}$ ratio are recorded within the samples in this study (e.g., 5.65, 38.43, 160.50) (see Table 3), which may indicate an arid climate and high salinity conditions during the time of their deposition.

A number of authors, including Yandoka et al. and Song et al., have suggested that the $\mathrm{Sr} / \mathrm{Cu}$ ratio can be used as an indicator of paleoclimate conditions [52,53]. According to these authors, the ratio values of $\mathrm{Sr} / \mathrm{Cu}$, which ranges from 1.3-5, indicate a warm humid climate, whilst values of $>5$ indicate a hot and arid climate. High $\mathrm{Sr} / \mathrm{Cu}$ values (i.e., $>5$ ) were observed from the samples of the Sarki, Sehkanyian, Sargelu, Naokelekan, Barsarin and Chia Gara formations (see Table 3). Thus, the climate was most probably hot and arid. These results agree with the results obtained from the $\mathrm{Sr} / \mathrm{Ba}$ ratio (see above).

The inverse relationship between the $\mathrm{Sr} / \mathrm{Cu}$ ratio and the $\mathrm{Rb} / \mathrm{Sr}$ ratio values are also used as paleoclimatic indications $[38,39]$. Within the samples of the Sarki, Sehkanyian, Sargelu, Naokelekan, Barsarin and Chia Gara formations, the $\mathrm{Sr} / \mathrm{Cu}$ ratio values increase (e.g., 20.23, 67.32, 183.09) with a consistent decrease in the $\mathrm{Rb} / \mathrm{Sr}$ ratio values (e.g., 0.34, 0.08, 0.02) (see Table 3). The inverse relationship between the two ratios (i.e., $\mathrm{Sr} / \mathrm{Cu}$ and $\mathrm{Rb} / \mathrm{Sr}$ ) would suggest that the depositional area underwent a warm climate during the deposition of the Sarki, Sehkanyian, Sargelu, Naokelekan, Barsarin and Chia Gara formations [38,39]. Similarly, Al-Lhaebi et al. examined the Cenomanian-Turonian boundary of the Gulneri 
Formation in the Azmir, Dokan and Degala sections in Northern Iraq using some selected geochemical data, including $\mathrm{Rb} / \mathrm{Sr}, \mathrm{Sr} / \mathrm{Cu}$ and $\mathrm{Sr} / \mathrm{Ba}$ ratios, and suggested that warm and arid conditions were predominant in the Cenomanian-Turonian transition [3]. Another study used $\mathrm{Rb} / \mathrm{Sr}, \mathrm{Sr} / \mathrm{Cu}$ and $\mathrm{Sr} / \mathrm{Ba}$ ratios as paleoclimate and paleosalinity indicators in their mineralogical and geochemical study of the Late Triassic Baluti Formation in the Baluti (formerly Zewa) village in northern Iraq [54]. They also suggested that the climate during the time of deposition of the Baluti sediments was hot and arid to semi-arid.

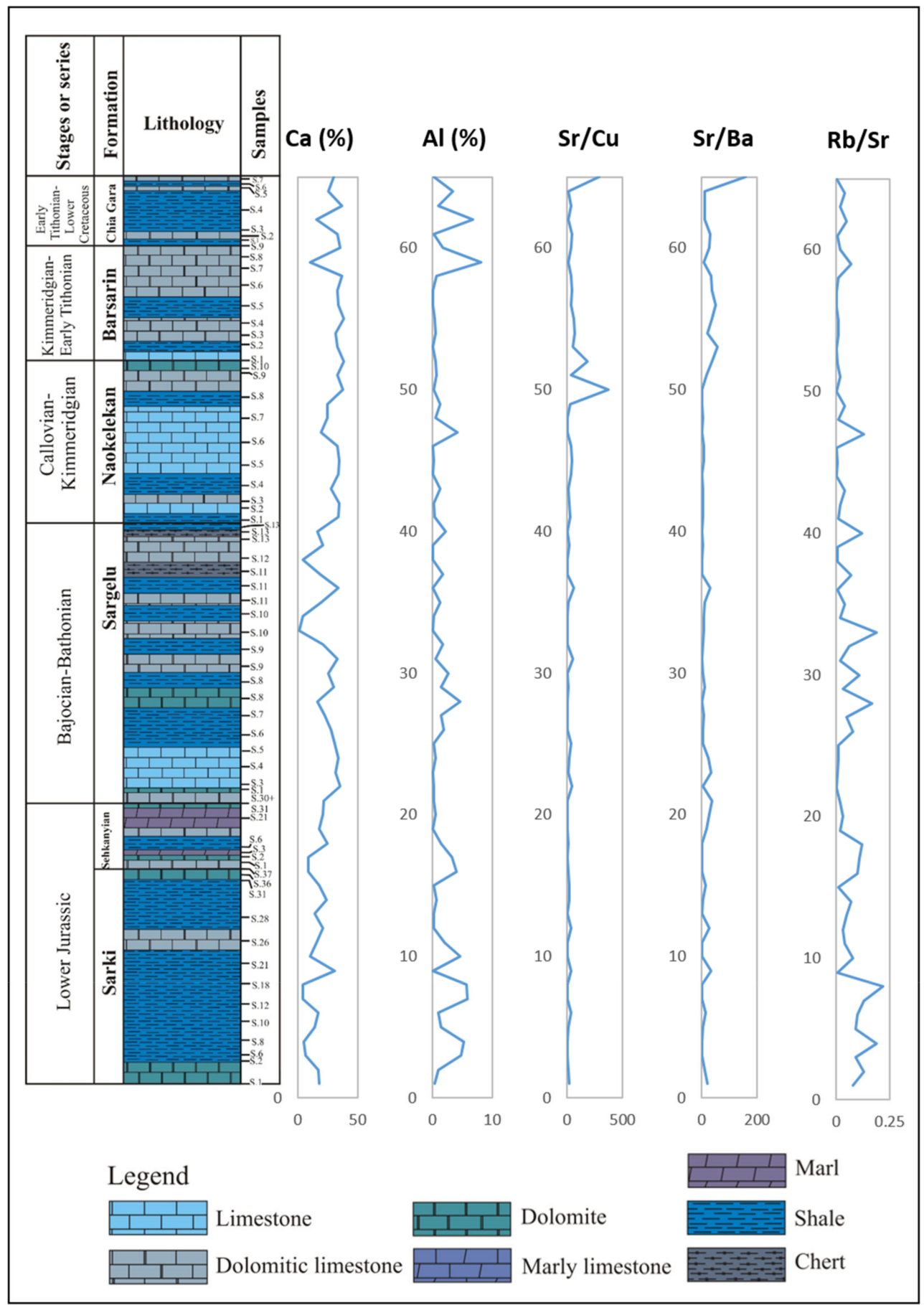

Figure 6. Chart showing geochemical proxies for paleoclimate conditions along the measured log of the Warte section, northeastern Iraqi Kurdistan. 
In summary, the analysis of the various elemental ratios used in this study would suggest that the climate at the time of deposition was one that was warm and arid. Furthermore, these conditions prevailed throughout much of the Jurassic and extended into the Early Cretaceous. The aridity of the Jurassic correlates well with the dominance of warming that characterized the Jurassic period globally [55,56]. In addition, the deposition of the upper part of the Early-Cretaceous-age Qamchuqa Formation in northeastern Iraq coincided with increased temperatures and salinities in the region, related to restriction of circulation [57].

\subsection{Paleoecological Proxies}

Calcareous nannofossils and geochemical analyses were used to reconstruct the paleoecological conditions of the depositional area of the Sarki, Sehkanyian, Sargelu, Naokelekan, Barsarin and Chia Gara formations, including examination of water temperatures and salinities.

According to Svobodová and Košták [58], calcareous nannofossils can provide important information about the paleoecological conditions of the depositional settings, in terms of water temperature and salinity [59-62]. The calcareous nannofossil Watznaueria manivitiae is considered by a variety of authors to be indicative of warm waters $[63,64]$, and thus, the increase in the number of Watznaueria manivitiae (see above) may indicate episodes of water warming.

In addition to geochemical proxies, oxygen isotope analysis was also used. Oxygen isotopes have been used by a variety of authors to indicate ancient water temperatures [5-7]. In general, negative values are considered to be indicative of warm waters [5-7], while positive values are indicative of cool waters. As noted above, the values from the various formations of NE Iraq are all negative, with one exception. The lowermost sample from the Sarki Formation is slightly positive (Table 2 and Figure 7). This persistence of negative oxygen isotope values from the Early Jurassic-Early Cretaceous-age formations of NE Iraq in this study resembles the results obtained for the same stratigraphic interval in the Duhok Governate of NW Iraq. There, the results were interpreted as being indicative of warm waters during the period [65].

As noted above, calcareous nannofossils can also provide important information regarding ancient water salinities. According to Tremolada et al. and Abdula, the presence of the nannofossil Cyclagelosphaera margerelii is considered to be indicative of high salinities $[14,66]$. In four of the formations from NE Iraq (i.e., Sargelu, Naokelekan, Barsarin and Chia Gara), up to $38 \%$ of the recovered nannofossil species were Cyclagelosphaera margerelii, which is suggestive of high salinities at that time.

Values of the trace element $\mathrm{Sr}$ have been used by a number of authors as a proxy for salinity and/or evaporation conditions [17,42-44]. According to these authors, increased Sr values are considered to be indicative of high salinity and/or evaporation conditions within the depositional setting. High Sr values were noted from the samples of the Sarki, Sehkanyian, Sargelu, Naokelekan, Barsarin and Chia Gara formations of NE Iraq (e.g., 82, 223, 504) (see Table 3 and Figure 7), which would suggest that both salinities and evaporation rates within the depositional area were high. Omar et al. has also suggested that salinity conditions and rates of evaporation (controlled by arid climate) were high within the depositional area of the Middle-Late Jurassic-age Sargelu and Naokelekan formations in northernmost Iraq [17]. This suggestion was based on the observed high Sr values within the samples of these Middle-Upper Jurassic formations.

In conclusion, these paleoecological findings correspond strongly with those from the paleoclimate proxies as detailed above; therefore, this study suggests that the deposition of the Sarki, Sehkanyian, Sargelu, Naokelekan, Barsarin and Chia Gara formations of NE Iraq occurred under arid conditions, with elevated salinities and high evaporation rates. These environmentally stressful conditions may also explain the poor preservation of the calcareous nannoplankton specimens throughout the entire investigated interval. 


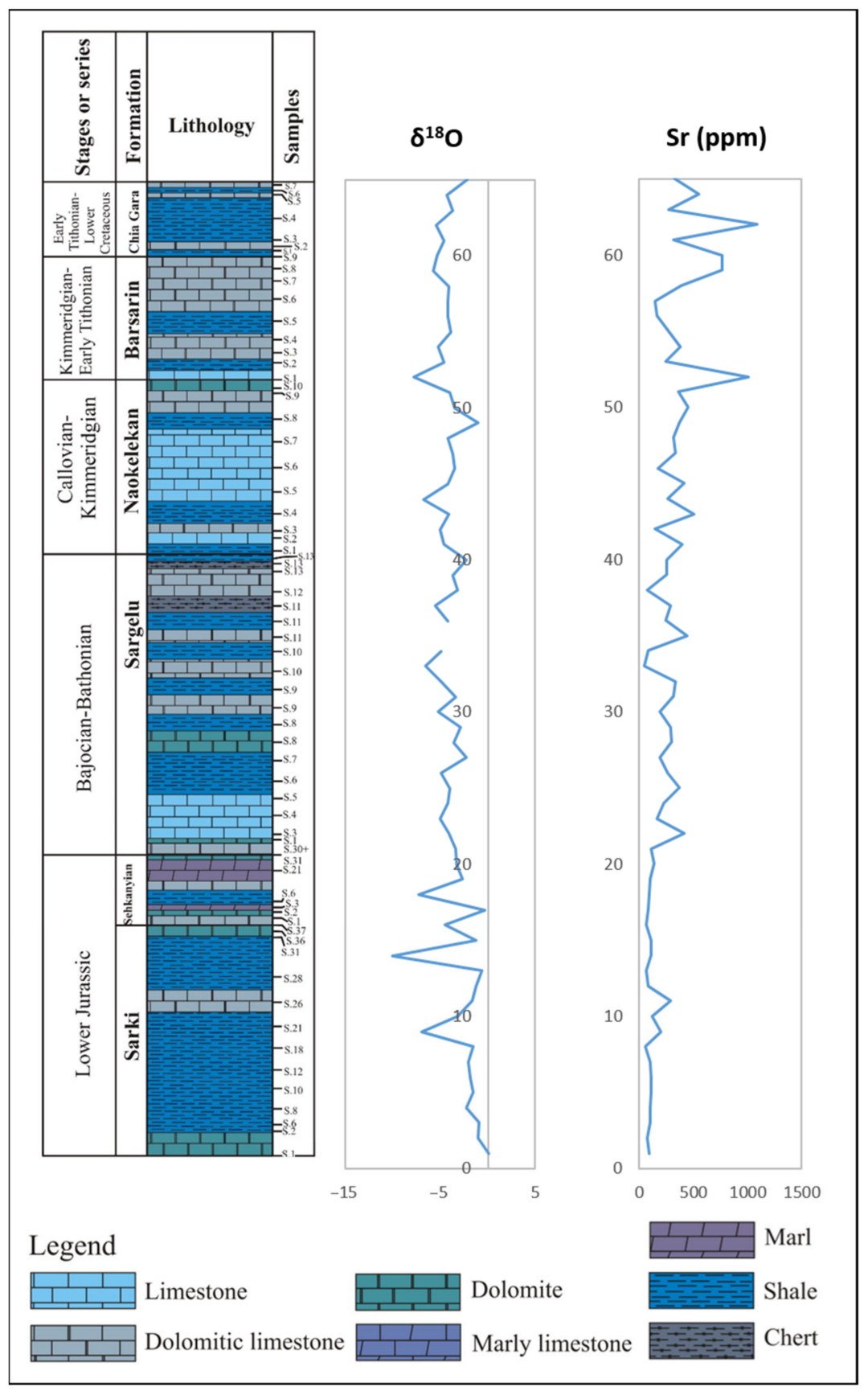

Figure 7. Chart showing geochemical proxies for paleoecological conditions along the measured log of the Warte section, northeastern Iraqi Kurdistan.

\section{Conclusions}

Calcareous nannofossils from the Lower Jurassic to Lower Cretaceous succession of the Warte section from northeastern Iraqi Kurdistan region were investigated for the first time. The calcareous nannoplankton are moderately to poorly preserved in the Warte sediments. The recovered nannofossil assemblages were recorded from the Middle JurassicEarly Cretaceous-age Sargelu, Naokelekan, Barsarin and Chia Gara formations, including W. barnesiae, $W$. fossacincta, $W$. britannica, W. manivitiae and C. margerelii, whilst the EarlyJurassic-age Sarki and Sehkanyian formations were barren.

The first occurrence of Cyclagelosphaera margerelii, Watznaueria britannica, W. fossacincta, W. manivitiae, Watznaueria barnesiae and Watznaueria ovata within the Sargelu Formation suggests an age of Bajocian-Callovian for the latter formation. 
More detailed geochemical analyses, including oxygen isotopes and paleoclimate and paleoecological proxies, indicated warm and arid conditions prevailing during the Early Jurassic-Early Cretaceous transition.

Author Contributions: Conceptualization, N.O., T.M. and A.I.A.-J.; methodology, N.O., T.M. and A.I.A.-J.; validation, N.O., T.M., A.I.A.-J. and M.A.U.; formal analysis, N.O., T.M. and M.A.U.; investigation, N.O., A.I.A.-J. and A.O.S.; resources, N.O., A.I.A.-J. and A.O.S.; writing-original draft preparation, N.O.; writing-review and editing, N.O., T.M., A.I.A.-J. and M.A.U.; supervision, T.M. and A.I.A.-J.; funding acquisition, N.O. All authors have read and agreed to the published version of the manuscript.

Funding: This work was supported by the Arab-German Young Academy of Sciences and Humanities (AGYA) that is funded under the German Ministry of Education and Research (BMBF) grant 01DL20003.

Data Availability Statement: Not applicable.

Conflicts of Interest: The authors declare no conflict of interest.

\section{References}

1. Mutterlose, J.; Bottini, C. Early Cretaceous chalks from the North Sea giving evidence for global change. Nat. Commun. 2013, 4, 1686. [CrossRef]

2. Reolid, M.; Emanuela, M.; Nieto, L.M.; Rodríguez-Tovar, F.J. The Early Toarcian Oceanic Anoxic Event in the External Subbetic (Southiberian Paleomargin, Westernmost Tethys): Geochemistry, nannofossils and ichnology. Paleogeogr. Paleoclimatol. Paleoecol. 2014, 411, 79-94. [CrossRef]

3. Al-Lhaebi, S.F.; Al-Badrani, O.A.; Al-Juboury, A.I.; Mahanipour, A. Paleoclimatic insights on the Cenomanian-Turonian Oceanic Anoxic Event (OAE2) from Northern Iraq based on calcareous nannofossils and geochemical data. Iraqi Geol. J. 2020, 53, 68-86. [CrossRef]

4. Al-Miamary, F.A.; Al-Badrani, O.A.; Al-Juboury, A.I. Calcareous nannofossils and chemostratigraphy of the Early Aptian Oceanic Anoxic Event 1a from Northern Iraq. Bull. Iraq Nat. Hist. Mus. 2020, 16, 363-379. [CrossRef]

5. Bartolini, A.; Pittet, B.; Mattioli, E.; Hanziker, J.C. Shallow-platform paleoenvironmental conditions recorded in deep-shelf sediments: $\mathrm{C}$ and $\mathrm{O}$ stable isotopes in Upper Jurassic sections of southern Germany (Oxfordian-Kimmeridgian). Sediment. Geol. 2003, 160, 107-130. [CrossRef]

6. Weissert, H.; Erba, E. Volcanism CO2 and paleoclimate: A late Jurassic-Early Cretaceous carbon and oxygen isotopes record. J. Geol. Soc. Lond. 2004, 161, 695-702. [CrossRef]

7. Ruf, M.; Link, E.; Pross, J.; Aigner, T. Integrated sequence stratigraphy: Facies, stable isotope, and palynofacies analysis in a deeper epicontinental carbonate ramp (Late Jurassic, SW Germany). Sediment. Geol. 2005, 175, 391-414. [CrossRef]

8. Mahanipour, A.; Mutterlose, J.; Eftekhari, M. Calcareous nannofossils of the Barremian-Aptian interval from the southeastern Tethys (Zagros Basin, West Iran) and their paleoceanographic implications: A record of Oceanic Anoxic Event 1a. Mar. Micropaleontol. 2019, 149, 64-74. [CrossRef]

9. Daoud, H.S.; Karim, K.H. Types of stromatolites in the Barsarin Formation (late Jurassic), Barzinja area, NE Iraq. Iraqi Bull. Geol. Min. 2006, 6, 47-57.

10. Al-Ameri, T.K.; Zumberge, J. Middle and Upper Jurassic hydrocarbon potential of the Zagross Fold Belt, North Iraq. Mar. Pet. Geol. 2012, 36, 13-34. [CrossRef]

11. Al-Juboury, A.I.; McCann, T. Petrological and geochemical interpretation of Triassic-Jurassic boundary sections from North Iraq. Geol. J. 2013, 50, 157-172. [CrossRef]

12. Jasim, S.Y. The potential of hydrocarbons generation in the Chia Gara Formation at Amadia area, north of Iraq. Arab. J. Geosci. 2013, 6, 3313-3318. [CrossRef]

13. Abdula, R. Source rock assessment of Naokelekan formation in Iraqi Kurdistan. JZS Part A 2017, 19, 103-124. [CrossRef]

14. Abdula, R.A. Stratigraphy and lithology of Naokelekan Formation in Iraqi Kurdistan Review. Int. J. Eng. Sci. 2016, 5, 7-17.

15. Wimbledon, W.A.P.; Mohialdeen, I.M.J.; Andreini, G.; Rehakova, D.; Stoykova, K. The Jurassic /Cretaceous boundary beds in Kurdistan-a preliminary note on wider correlations. JZS Spec. Issue GeoKurd. 2016, 2, 269-276. [CrossRef]

16. Liu, X.; Wen, Z.; Wang, Z.; Song, C.; He, Z. Structural characteristics and main controlling factors on petroleum accumulation in Zagros Basin, Middle East. J. Nat. Gas. Geosci. 2018, 5, 273-281. [CrossRef]

17. Omar, N.; McCann, T.; Al-Juboury, A.I.; Franz, S.O. Petrography and geochemistry of the Middle-Upper Jurassic Banik section, northernmost Iraq-implications for paleoredox, evaporitic and diagenetic conditions. N. Jb. Geol. Paleont. Abh. 2020, 297, 125-152. [CrossRef]

18. Omar, N.; McCann, T.; Al-Juboury, A.I.; Suárez-Ruiz, I. Solid bitumen in shales from the Middle to Upper Jurassic Sargelu and Naokelekan Formations of northernmost Iraq: Implication for reservoir characterization. Arab. J. Geos. 2021, 14, 755. [CrossRef] 
19. Beydoun, Z.R.; Clarke, M.W.H.; Stoneley, R. Petroleum in the Zagros Basin a Late Tertiary foreland basin overprinted onto the outer edge of a vast hydrocarbonrich Paleozoic Mesozoic passive margin shelf. In Foreland Basins and Fold Belts; MacQueen, R.W., Leckie, D.A., Eds.; AAPG Memoir: Tulsa, OK, USA, 1992; Volume 55, pp. 309-339. [CrossRef]

20. Talbot, C.J.; Alavi, M. The past of a future syntax is across the Zagros. In Salt Tectonics; Alsop, G.I., Blundell, D.J., Davison, I., Eds.; Special Publication; Geological Society: London, UK, 1996; Volume 100, pp. 89-109. [CrossRef]

21. Stampfli, G.M.; Borel, G.D. A plate tectonic model for the Paleozoic and Mesozoic constrained by dynamic plate boundaries and restored synthetic oceanic isochrons. Earth Planet. Sci. Lett. 2002, 196, 17-33. [CrossRef]

22. Bellen, R.C.V.; Dunnington, H.V.; Wetzel, R.; Morton, D.M. Asie, Fascicule 10a Iraq; Lexique Stratigraphic International: Paris, France, 1959; Volume 3, p. 333.

23. Numan, N.M.S. Major cretaceous tectonic events in Iraq. Raf. J. Sci. 2000, 11, 32-52.

24. Jassim, S.Z.; Goff, J.C. Geology of Iraq; Dolin, Prague \& Moravian Museum: Brno, Czech Republic, 2006; p. 352.

25. Fouad, S.F.A. Tectonic Map of Iraq, Scale 1: 1000,000, 3rd ed.; Iraqi Bulletin of Geology and Mining: Baghdad, Iraq, 2015; Volume 11, pp. 1-7.

26. Balaky, S.M.; Asaad, I.S.; Al-Juboury, A.I. Facies analysis and sequence stratigraphy of Kometan Formation (Upper Cretaceous) in the imbricated zone, northeastern Iraq. Arab. J. Geosci. 2016, 9, 747. [CrossRef]

27. Dunnington, H.V. Generation, migration, accumulation and dissipation of oil in Northern Iraq. In Habitat of Oil, a Symposium; Weeks; American Association of Petroleum Geologists: Tulsa, OK, USA, 1958; pp. 1194-1251.

28. Wetzel, R.; Morton, D.M.; Formation, S.; Van Bellen, R.C.; Dunnington, H.V.; Wetzel, R.; Morton, D.M. (Eds.) Paris, III, Asie, Fascicule 10a Iraq; Lexique Stratigraphic International: Paris, France, 1950; pp. 211-215.

29. Sissakian, V.K. Geological Maps in the Kurdistan Region. UKH J. Sci. Eng. 2018, 2, 39-42. [CrossRef]

30. Al-Omari, F.S.; Sadiq, A. Geology of Northern Iraq: Mosul, Iraq; Mosul University Press: Mosul, Iraq, 1977 ; p. 198.

31. Jassim, S.Z.; Buday, T. Late Toarcian-Early Tithonian (Mid-Late Jurassic) Megasequence AP7. In Geology of Iraq; Jassim, S.Z., Goff, J.C., Eds.; Moravian Museum: Brno, Prague, 2006; pp. 117-123.

32. Buday, T. The Regional Geology of Iraq. Stratigraphy and Palaeogeography; Publication of GEOSURV: Baghdad, Iraq, 1980; Volume 1, p. 445.

33. Fisher, J.K.; Price, G.D.; Hart, M.B.; Leng, M.J. Stable isotope analysis of the Cenomanian-Turonian (Late Cretaceous) oceanic anoxic event in the Crimea. Cretac. Res. 2005, 26, 853-863. [CrossRef]

34. Allan, J.R.; Matthews, R.K. Isotope signatures associated with early meteoric diagenesis. Sedimentology 1982, 29, 797-817. [CrossRef]

35. Azmy, K.; Poty, E.; Brand, U. High-resolution isotope stratigraphy of the Devonian-Carboniferous boundary in the Namur-Dinant Basin, Belgium. Sediment. Geol. 2009, 216, 117-124. [CrossRef]

36. Li, X.; Wei, Y.; Li, Y.; Zhang, C. Carbon isotope records of the early Albian oceanic anoxic event (OAE) 1b from eastern Tethys (southern Tibet, China). Cretac. Res. 2016, 62, 109-121. [CrossRef]

37. Hennhoefer, D.; AL Suwaidi, A.; Bottini, C.; Helja, E.; Steuber, T. The Albian to Turonian carbon isotope record from the Shilaif Basin (United Arab Emirates) and its regional and intercontinental correlation. Sedimentology 2018, 66, 536-555. [CrossRef]

38. Sinha, R.; Smykatz-Kloss, W.; Stüben, D.; Harrison, S.P.; Berner, Z.; Kramar, U. Late Quaternary paleoclimatic reconstruction from the lacustrine sediments of the Sambhar playa core, Thar Desert margin, India. Paleogeogr. Paleoclimatol. Paleoecol. 2006, 233, 252-270. [CrossRef]

39. Xu, H.; Liu, B.; Wu, F. Spatial and temporal variations of Rb/Sr ratios of the bulk surface sediments in Lake Qinghai. Geochem. Trans. 2010, 11, 1-8. [CrossRef]

40. Wang, Z.; Fu, X.; Feng, X.; Song, C.; Wang, D.; Chen, W.; Zeng, S. Geochemical features of the black shales from the Wuyu Basin, southern Tibet: Implications for paleoenvironment and paleoclimate. Geol. J. 2017, 52, 282297. [CrossRef]

41. Orhan, H.; Delikan, A.; Demir, A.; Kapan, S.; Olgun, K.; Özmen, A.; Sayin, Ü.; Ekici, G.; Aydin, H.; Nazik, A. Geochemical evidences of paleoenvironmental changes in Late Quaternary lacustrine sediments of the Konya Closed Basin (Konya, Turkey). In Patterns and Mechanisms of Climate, Paleoclimate and Paleoenvironmental Changes from Low Latitude Regions; Zhang, Z., Khelifi, N., Mezghani, A., Heggy, E., Eds.; Springer: Berlin, Germany, 2019; pp. 73-76. [CrossRef]

42. Read, J.F.; Kerans, C.; Weber, L.J.; Sarg, H.F.; Wright, F.M. Milankovitch sea level changes, cycles and reservoirs on carbonate platforms in greenhouse and ice-house worlds. SEPM Soc. Sediment. Geol. 1995, 35, 1-81. [CrossRef]

43. Price, G.D. The evidence and implications of polar ice during the Mesozoic. Earth Sci. Rev. 1999, 48, 183-210. [CrossRef]

44. Vincent, B.; Rambeau, C.; Emmanuel, L.; Loreaue, J.P. Sedimentology and trace element geochemistry of shallow-marine carbonates: An approach to paleoenvironmental analysis along the Pagny-sur-Meuse Section (Upper Jurassic, France). Facies 2006, 52, 69-84. [CrossRef]

45. Gradstein, F.M.; Ogg, J.G.; Schmitz, M.; Ogg, G. Geologic Time Scale 2020, 1st ed.; Elsevier: Amsterdam, The Netherlands, 2020; p. 1357. [CrossRef]

46. Bralower, T.J.; Monechi, S.; Thierstein, H.R. Calcareous nannofossil zonation of the Jurassic-Cretaceous boundary interval and correlation with the geomagnetic polarity timescale. Mar. Micropaleontol. 1989, 14, 153-235. [CrossRef]

47. Bown, P.R.; Cooper, M.K.E. Jurassic. In Calcareous Nannofossil Biostratigraphy; British Micropaleontological Society Publication Series; Springer: Berlin, Germany, 1998; pp. 34-85. 
48. Grün, W.; Zweili, F. Das kalkige Nannoplankton der Dogger-Malm-Grenze im Berner Jura bei Liesberg (Schweiz). Jb. Geol. B-A 1980, 123, 231-341.

49. Gollain, G.; Mattioli, E.; Kenjo, S.; Bartolini, A.; Reboulet, S. Size patterns of the coccolith Watznaueria barnesiae in the lower Cretaceous: Biotic versus abiotic forcing. Mar. Micropaleontol. 2019, 152, 101740. [CrossRef]

50. Rai, J.; Garg, R. Early Callovian nannofossils from the Kuldhar section, Jaisalmer, Rajasthan. Curr. Sci. 2007, 92, 816-820.

51. Jain, S.; Singh, A. First calcareous nannofossil record from the Jurassic strata exposed in the Blue Nile Basin (Ethiopia). J. Afr. Earth Sci. 2019, 158, 103553. [CrossRef]

52. Yandoka, B.M.S.; Abdullah, W.H.; Abubakar, M.B.; Hakimi, M.H.; Adegoke, A.K. Geochemical characterization of early Cretaceous lacustrine sediments of Bima Formation, Yola Sub-basin, northern Benue trough, NE Nigeria: Organic matter input, preservation, paleoenvironment and paleoclimatic conditions. Mar. Petrol. Geol. 2015, 61, 82-94. [CrossRef]

53. Song, Y.; Liu, Z.; Meng, Q.; Xu, J.; Sun, P.; Cheng, L.; Zheng, G. Multiple controlling factors of the enrichment of organic matter in the upper cretaceous oil shale sequences of the Songliao basin, NE China: Implications from geochemical analyses. Oil Shale 2016, 33, 142-166. [CrossRef]

54. Hussain, S.H.; Al-Juboury, A.I.; Al-Haj, M.A.; Armstrong-Altrin, J.S.; Al-Lhaebi, S.F. Mineralogy and geochemistry of the Late Triassic Baluti Formation, Northern Iraq. J. Afr. Earth Sci. 2021, 181, 104243. [CrossRef]

55. Hallam, A. The Jurassic climate. In Climate in Earth History: Studies in Geophysics; The National Academies Press: Washington, DC, USA, 1982; pp. 159-163. [CrossRef]

56. Chao, H.; Hou, M.; Jiang, W.; Cao, H.; Chang, X.; Luo, W.; Ogg, J.G. Paleoclimatic and Redox Condition Changes during Early-Middle Jurassic in the Yili Basin, Northwest China. Minerals 2021, 11, 675. [CrossRef]

57. Ameen, B.M.; Karim, K.H. Depositional Environment of Early Cretaceous Arabian Platform: An example from Kurdistan Region, NE-Iraq. In Proceedings of the 3rd Scientific Conference of the College of Science, University of Baghdad, Baghdad, Iraq, 24-26 March 2009; pp. 1949-1961.

58. Svobodová, A.; Košták, M. Calcareous nannofossils of the Jurassic/Cretaceous boundary strata in the Puerto Escaño section (southern Spain)_Biostratigraphy and paleoecology. Geol. Carpath. 2016, 67, 223-238. [CrossRef]

59. Erba, E. Middle Cretaceous calcareous nannofossils from the western Pacific (Leg 129): Evidence for paleoequatorial crossings. In Proceedings of the Ocean Drilling Program, Scientific Results; Texas A\&M University: College Station, TX, USA, 1992; Volume 129, pp. 189-201. [CrossRef]

60. Tremolada, F.; Erba, E.; Bralower, T.J. Late Barremian to early Aptian calcareous nannofossils paleoceanography and paleoecology from the Ocean Drilling Program Hole 641C (Calicia Margin). Cretac. Res. 2006, 27, 887-897. [CrossRef]

61. Aguado, R.; O'Dogherty, L.; Sandoval, J. Fertility changes in surface waters during the Aalenian (mid-Jurassic) of the Western Tethys as revealed by calcareous nannofossils and carbon-cycle perturbations. Mar. Micropaleontol. 2008, 68, 268-285. [CrossRef]

62. Mattioli, E.; Pittet, B.; Suan, G.; Mailliot, S. Calcareous nannoplankton changes across the early Toarcian oceanic anoxic event in the western Tethys. Paleoceanography 2008, 23, PA3208. [CrossRef]

63. Tremolada, F.; Erba, E.; van de Schootbrugge, B.; Mattioli, E. Calcareous nannofossil changes during the late Callovian-early Oxfordian cooling phase. Mar. Micropaleontol. 2006, 59, 197-209. [CrossRef]

64. Giraud, F. Calcareous nannofossil productivity and carbonate production across the Middle-Late Jurassic transition in the French Subalpine Basin. Geobios 2009, 42, 699-714. [CrossRef]

65. AL-Badry, A.M.S. Stratigraphy and Geochemistry of Jurassic Formations in Selected Sections-North Iraq. Ph.D. Thesis, College of Science, University of Baghdad, Baghdad, Iraq, 2012; p. 162.

66. Tremolada, F.; Bornemann, A.; Bralower, T.J.; Koeberl, C.; van de Schootbrugge, B. Paleooceanographic changes across the Jurassic/Cretaceous boundary-The calcareous phytoplankton response. Earth Planet. Sci. Lett. 2006, 241, 361-371. [CrossRef] 